\title{
GLAZE TECHNOLOGY OF HISPANO-MORESQUE CERAMIC TILES: A COMPARISON BETWEEN PORTUGUESE AND SPANISH COLLECTIONS
}

\author{
S. Coentro ${ }^{1}$, L.C. Alves ${ }^{2}$, C. Relvas ${ }^{3}$, T. Ferreira ${ }^{3}$, J. Mirão ${ }^{4}$, J. Molera ${ }^{5}$, T. Pradell ${ }^{6}$, \\ R.A.A. Trindade ${ }^{7}$, R.C. da Silva ${ }^{8}$, V.S.F. Muralha ${ }^{1 \dagger}$
}
1 VICARTE - Research Unit "Glass and Ceramic for the Arts", Faculdade de Ciências e Tecnologia, Universidade Nova de Lisboa, 2829-516 Caparica, Portugal - scoentro@campus.fct.unl.pt
${ }^{2}$ C2TN-IST/UL, Centro de Ciências e Tecnologia Nucleares, Instituto Superior Técnico, Universidade de Lisboa, Estrada Nacional 10, 2695-066 Bobadela, Portugal
${ }^{3}$ Departamento de Química, Laboratório HERCULES, Escola de Ciência e Tecnologia, Universidade de Évora, Largo Marquês de Marialva, 8, 7000-809 Évora, Portugal
${ }^{4}$ Departamento de Geociências, Laboratório HERCULES, Escola de Ciência e Tecnologia, Universidade de Évora, Largo Marquês de Marialva, 8, 7000-809 Évora, Portugal

${ }^{5}$ MECAMAT, U Science Tech, University of Vic - Central University of Catalonia, C. de la Laura 13, 08500 Vic, Spain

${ }^{6}$ Dpt. Física i Enginyeria Nuclear, Universitat Politècnica de Catalunya, Esteve Terradas 8, 08860 Castelldefels, Spain
${ }^{7}$ Museu Nacional de Arte Antiga (MNAA), Rua das Janelas Verdes, 1249-017 Lisboa, Portugal 8 IPFN-IST/UL, Instituto de Plasmas e Fusão Nuclear, Instituto Superior Técnico, Universidade de Lisboa, Estrada Nacional 10, 2695-066 Bobadela, Portugal - rmcs@ctn.ist.utl.pt

\section{ABSTRACT}

For the first time, Hispano-Moresque glazed tiles from Portuguese and Spanish collections were studied together and compared. This work is included in a wider study tackling the technology of Hispano-Moresque tile production from several collections in the Iberian Peninsula. While showing many similarities, differences were identified between collections, regarding both chemical and morphological characteristics. The collection from Mosteiro de Santa Clara-a-

\footnotetext{
† in memoriam of our co-author and dear friend V.S.F. Muralha
} 
Velha (Coimbra) stands out from the other collections, with higher $\mathrm{SnO}_{2}$ content (up to $14 \% \mathrm{wt}$.), the highest $\mathrm{Fe}_{2} \mathrm{O}_{3}$ contents in amber glazes, and a Ca-rich interface layer (mostly comprised of wollastonite, $\mathrm{CaSiO}_{3}$ ). Samples from Palácio Nacional de Sintra (near Lisbon) and Sevilleattributed samples (from Instituto Valencia de Don Juan) are chemically similar, except that most Sintra's samples display a K-rich glaze-ceramic interface, whereas the ones from Seville exhibit both K-rich and Ca-rich inclusions. The samples attributed to Toledo show glazes with many inclusions, contrasting with the homogeneous glazes in most Hispano-Moresque tiles. From these results we identify differences that can be used as markers in future studies on Hispano-Moresque tiles.

Keywords: Hispano-Moresque tiles, lead-tin glazes, $\mu$-PIXE, SR- $\mu$-XRD, SEM-EDS

\section{INTRODUCTION}

\section{Hispano-Moresque Ceramic Tiles}

The azulejo (glazed tile) is the highlight of Portuguese cultural heritage, notorious after the second half of the 16th century, when the relevant works that embody the Portuguese azulejo production begun. Nevertheless the designated Hispano-Moresque or medieval tiles were widely used in Portugal from the 15th century to the first half of the 16th century. Historically, this part of our cultural heritage has been considered to be imported from Spanish production centres, namely Seville, which by then was the main production centre in the Iberian Peninsula. There are indeed records of import orders to the Portuguese territory (Coimbra and Sesimbra), but archaeological evidences have shown that arista tiles were made in Portugal, near Barreiro, on the south bank of the Tagus River (Barros, 1999; Trindade, 2008; Vieira Ferreira et al., 2014). Therefore, this subject is not consensual in our historic panorama and, recently, an analytical study has begun aiming at contributing to settle this issue. In order to clarify this key issue in tile manufacture from the Iberian Peninsula, it is important to analyse and compare data from Spanish and Portuguese collections. As far as we know, this is the first study comparing the chemical, mineralogical and morphological characterisation of both 
Portuguese and Spanish collections of Hispano-Moresque architectural tiles. In a previous publication (Coentro et al., 2014), an important Portuguese collection was studied - the collection of the Mosteiro de Santa Clara-a-Velha, in Coimbra, Portugal. Those results are now compared with new data on tiles from Palácio Nacional de Sintra (Portugal) and on Spanish samples from Instituto Valencia de Don Juan (Madrid) attributed to Seville and Toledo. Hispano-Moresque tiles combine the technology of both tin-opacified glazes (usually for the whites and blues, but occasionally also for other colours) and transparent lead glazes. The production technology for this type of architectural decorations was inherited from the Muslims that occupied the Iberian Peninsula from the late $8^{\text {th }}$ century AD onwards. It was adopted, developed and also simplified in Moresque workshops (Molera et al., 1997, 2009; Ortega et al., 2012).

The glaze technology used in Hispano-Moresque tiles was the focus of this study: glaze compositions, colours and morphologies provide important information to compare production centres and contextualize tile production in the ceramics manufacture throughout the Iberian Peninsula.

\section{Collections}

The Palácio Nacional de Sintra (PNS) stands at least since the $13^{\text {th }}$ century, but most of its Hispano-Moresque decorations belong to King Manuel I reign (1495-1521). By the end of the $15^{\text {th }}$ century, major construction works took place in the Palace and thousands of HispanoMoresque tiles were used to decorate its walls. It is usually said that the tiles came from Seville and were unloaded in Belém seaport, in Lisbon. This idea is still under debate, since the document referring tiles in Belém does not mention their origin and there are very unusual motifs in the PNS collection, unknown anywhere else in the world, such as the armillary sphere and some relief tiles with wine-related motifs (Trindade 2008). Furthermore, it is now known that there was production of Hispano-Moresque tiles in the south bank of the river Tagus, as previously mentioned.

The Mosteiro de Santa Clara-a-Velha (SCV) was founded in 1283 and definitely abandoned in 1677. Located on the left bank of river Mondego, just opposing ancient Coimbra, the building 
suffered from constant floods that ultimately led to the construction of a new Santa Clara Monastery, on a higher location nearby (Côrte-Real et al., 2010). The church and cloister are now ruins that were partially restored and opened to the public. During the last decades, several archaeological campaigns uncovered an extraordinary Hispano-Moresque tile collection, including a variety of patterns and production techniques (arista, cuerda seca, relief and flat tiles).

The Instituto Valencia de Don Juan (IVDJ) is located in Madrid, Spain. It was founded in 1916 to host the collection of decorative arts and documents that comprises one of the most important sets of Hispano-Moresque ceramics in the world, including tiles from Seville, Toledo and Valencia. Its founders were the owners of such collection: Don Guillermo de Osma y Scull and his wife Doña Adelaida Crooke y Guzmán (XIII Condesa de Valencia de Don Juan).

\section{EXPERIMENTAL PROCEDURE}

\section{Samples}

Cross-section samples ( $1 \mathrm{~mm}$ to $2 \mathrm{~mm}$ wide) from the collections of Palácio Nacional de Sintra (PNS) and Instituto Valencia de Don Juan (IVDJ) were collected and mounted in epoxy resin (Araldite® 2020). They were all polished in Micro-Mesh® sheets up to grit $8000 . \mu$-PIXE, $\mu$ Raman and SEM-EDS analyses were performed on these polished cross-section samples. Only $\mu-\mathrm{XRD}$ analysis required thin-cut polished cross-sections, as explained below.

Results were compared with the ones from our previous publication on the collection of Mosteiro de Santa Clara-a-Velha (SCV) (Coentro et al., 2014). In total 70 samples were studied (each one of them comprising several coloured glazes): 30 from PNS collection, 19 from SCV collection and 21 from IVDJ collection. In the latter set there are samples attributed to Toledo and to Seville, indicated as IVDJ-T and IVDJ-S, respectively, in Tables and Figures. A tile from each collection is represented in Figure S1 (supplementary material).

\section{Analytical Techniques}


$\mu$-PIXE: Particle Induced X-Ray Emission with micrometre lateral resolution ( $\mu$-PIXE) was performed using an Oxford Microbeams OM150 type scanning microprobe capable both of focusing down to $3 \times 4 \mu \mathrm{m}^{2}$ the used $1 \mathrm{MeV}$ proton beam and scanning a sample surface area as large as $3730 \times 3730 \mu \mathrm{m}^{2}$. The sample fragments were irradiated in vacuum and a $30 \mathrm{~mm}^{2}$ Bruker SDD with $145 \mathrm{eV}$ resolution was used for $\mathrm{X}$-ray collection. Equipped with a $8 \mu \mathrm{m}$ thick Be window, it allows detecting $\mathrm{X}$-ray energies as low as the ones of $\mathrm{Na}$ while preventing most of the protons from entering and damaging the detector crystal. From the initially obtained 2D elemental distribution maps (with typical dimensions of $750 \times 750 \mu \mathrm{m}^{2}$ ), the glaze and the ceramic body of the tiles could be properly identified and a representative region of interest selected for quantitative analysis. Operation and basic data manipulation was achieved through the OMDAQ software code (Grime and Dawson, 1995), while quantitative analysis was performed with the GUPIX code (Campbell et al., 2010). In order to validate the results, two glass reference standards (Corning Museum of Glass B and C) were also analysed (Table 1).

SEM-EDS: The equipment used for the analyses was a variable pressure scanning electron microscope HITACHI S-3700N coupled with a Bruker Xflash 5010 SDD energy dispersive X-ray spectrometer. Samples were analysed either in vacuum (in which case, the samples were coated with a thin, conductive film of carbon), or under an air pressure of $20 \mathrm{~Pa}$ or $40 \mathrm{~Pa}$ (with uncoated samples). The backscattering mode was used for SEM imaging. The resolution of the EDS detector is $123 \mathrm{eV}$ at the $\mathrm{Mn}$ Ka line energy. The system allows reliable chemical point analysis and mapping from $\mathrm{Na} \mathrm{Ka} \mathrm{X-ray} \mathrm{emission} \mathrm{energy} \mathrm{up} \mathrm{to} \mathrm{the} \mathrm{L} \mathrm{emissions} \mathrm{of} \mathrm{the} \mathrm{heaviest}$ elements. In order to collect $\mathrm{X}$-ray emissions from heavier elements like $\mathrm{Pb}$, an acceleration voltage of $20 \mathrm{kV}$ was chosen. The EDS tasks and the quantification were achieved through the Esprit1.9 software from Bruker Corporation.

$\mu$-Raman: Analyses were performed with a Labram 300 Jobin Yvon spectrometer, equipped with a He-Ne laser of $17 \mathrm{~mW}$ power operating at $633 \mathrm{~nm}$ and a solid state laser of $500 \mathrm{~mW}$ power operating at $532 \mathrm{~nm}$. The laser beam was focused either with 50x or 100x Olympus objective lenses. The laser power was filtered to $10 \%$ incident power using a neutral density 
filter for all analyses. Analyses were performed both on the surface of the glazes and on polished cross-sections. Spectra were recorded as an extended scan. A mixed GaussianLorentzian curve-fit provided by the LabSpec software ( $v$ 5.15.25) was used to determine the exact peak wavenumbers. The attribution of the Raman spectra was made using the RRUFF database project on minerals (RRUFF, 2014).

$\mu$-Diffraction: Analyses were performed in the Material Science Powder Diffraction (MSPD) beamline at the Spanish synchrotron ALBA-CELLS. Small fragments (a few millimetres) of 8 samples from PNS, SCV and IVDJ collections were embedded in an epoxy resin and fixed onto a glass microscope slide. Thin sections of $30 \mu \mathrm{m}$ thick were obtained by grinding by hand and samples were polished with 1 micron diamond paste in order to be studied under the petrographic microscope. Using a polished thin cut, it is also possible to study the nature and spatial distribution of the crystalline compounds by microscopy and the same thin section is used for $\mu$-Difraction analyses. Micro-X-ray diffraction with synchrotron radiation (SR- $\mu$-XRD) was performed using $0.04133 \mathrm{~nm}$ wavelength (30 keV), spot size of $20 \mu \mathrm{m} \times 20 \mu \mathrm{m}$ and recorded using a SX165 Rayonix CCD detector.

\section{RESULTS AND DISCUSSION}

The ceramic body of the tiles is briefly described here, as this study is focused on the glazes. $\mu$ PIXE analysis performed on the ceramic bodies revealed similar compositions in most samples, with a Ca-rich composition (ca. 15-25 wt.\% CaO) consistent with the creamy-pink colour range. The main constituent oxides are $\mathrm{SiO}_{2}, \mathrm{CaO}, \mathrm{Al}_{2} \mathrm{O}_{3}, \mathrm{Fe}_{2} \mathrm{O}_{3}, \mathrm{MgO}$ and $\mathrm{K}_{2} \mathrm{O}$, with $\mathrm{SiO}_{2}$ values between $47 \mathrm{wt} . \%$ and $60 \mathrm{wt} . \%$ and $\mathrm{Al}_{2} \mathrm{O}_{3}$ contents in the $11-17 \mathrm{wt} . \%$ range. IVDJ-T samples stand out for their orange ceramic bodies, although quantitative analysis did not reveal considerable differences when compared to the other collections. Higher hematite $\left(\mathrm{Fe}_{2} \mathrm{O}_{3}\right)$ contents may explain the orange hues, whereas in SCV, PNS and IVDJ-S samples the iron ions 
may have been incorporated in pyroxenes and other phases that form at $900-950{ }^{\circ} \mathrm{C}$ (Molera et al., 1998). These differences will be addressed in a separate study to be published.

All samples in this study were decorated with glazes of the same five colours - white, blue, green, amber and brown - which look similar by visual inspection amongst all groups. However, different shades were identified and will be discussed separately for each colour.

Microprobe PIXE X-ray mapping and point analysis showed the occurrence of elemental distributions of $\mathrm{Sn}, \mathrm{Co}, \mathrm{Cu}, \mathrm{Fe}$ and $\mathrm{Mn}$ - elements known to confer colours in glazes - in tight correlation with the glazes colours: white $\left(\mathrm{SnO}_{2}\right)$, blue $\left(\mathrm{SnO}_{2}\right.$ and $\left.\mathrm{CoO}\right)$, green $(\mathrm{CuO})$, amber $\left(\mathrm{Fe}_{2} \mathrm{O}_{3}\right)$ and brown $(\mathrm{MnO})$. At the macroscopic and mesoscopic levels, the colours are very homogenous, while no particles or inclusions were identified by SEM-EDS or $\mu$-Raman that would suggest a particular raw material.

Content analysis for PNS, SCV and IVDJ samples, obtained through quantitative $\mu$-PIXE, are presented in Table 2 in summarised form. Detailed quantification results for each sample may be found in Table S1 - supplementary material (samples that were previously analysed in Coentro et al., 2014 are indicated accordingly). $\mathrm{SiO}_{2}$ and $\mathrm{PbO}$ are the major constituents of the glazes making up to $90 \mathrm{wt} . \%$ of the total composition. They show an inverse correlation (Figure 1a), with lower $\mathrm{SiO}_{2} / \mathrm{PbO}$ ratios for the majority of green, brown and amber glazes than for white and blue ones.

The chemical composition of the majority of glazes (namely in arista and cuerda seca tiles) can be divided in two groups according to their $\mathrm{SnO}_{2}$ content (Figure 1b), with blue and white glazes having higher $\mathrm{SnO}_{2}$ contents on one side (ca. 4-14 wt.\%), and most green, amber and brown glazes with lower values (ca. 0-3 wt.\% $\mathrm{SnO}_{2}$ ).

However, there are exceptions in the IVDJ and, in particular, the PNS collection, namely with some green and brown glazes having higher $\mathrm{SnO}_{2}$ content. In the PNS collection, these exceptions correspond to relief tiles, where, according to chemical analysis, a white tin-glaze seems to be the base recipe for all colours.

\section{Glaze analysis by colour}




\section{White and blue glazes}

PIXE characterization showed that tin oxide is the third major constituent in white and blue glazes for all three collections under study and is also one distinguishing factor amongst these collections, with higher $\mathrm{SnO}_{2}$ contents in white and blue glazes of the SCV collection (ca. 7-14 wt.\%). Figure 1c shows how SCV collection stands out from the others, with larger spread and a tendency to higher $\mathrm{SnO}_{2} / \mathrm{PbO}$ wt.\% ratios for most white and blue samples.

The PNS collection tiles have $\mathrm{SnO}_{2}$ contents that do not exceed 9 wt.\% (except for a flat monochromatic white sample, PNS04, which contains $12 \mathrm{wt}$ \% $\mathrm{SnO}_{2}$ ). IVDJ-S samples show higher amounts of $\mathrm{SnO}_{2}(5-11$ wt.\%) than IVDJ-T ones (4-8 wt.\%).

Figure $1 \mathrm{~b}$ shows that a higher $\mathrm{Na}_{2} \mathrm{O}$ content is associated with tin-opacified glazes, which suggests that a sodium compound could have been intentionally added, perhaps as a flux to compensate for the lower $\mathrm{PbO}$ contents.

When comparing with published data on coeval tin glazes, the results obtained for tin oxide contents in the PNS and IVDJ collections agree with Hispano-Moresque white glazes analysed by several authors (Chabanne et al., 2008; Molera et al., 1997, 2001b; Pérez-Arantegui et al., 2005, 2009; Vieira Ferreira et al., 2014). However, higher tin oxide contents, such as found in SCV samples, are not common in any type of known Hispano-Moresque ceramics and have only been measured in Islamic white glazed ceramics from Zaragoza and Córdoba (Molera et al., 2001b). The lack of specific studies on Hispano-Moresque tiles does not yet allow determining if this is a particular characteristic of SCV tiles or if high $\mathrm{SnO}_{2}$ contents were used in more tile collections throughout the Iberian Peninsula.

$\mathrm{Fe}_{2} \mathrm{O}_{3}$ contents in white glazes are mostly inferior to $1 \mathrm{wt} . \%$, which could mean that raw materials underwent some kind of purification process, or that a high-quality sand was used, low in impurities (Pérez-Arantegui et al., 2005, 2009).

Cross-sectional SEM shows that the large majority of Hispano-Moresque tiles in this study have very homogeneous tin-opacified glazes, with few mineral inclusions (mostly quartz and potassium feldspars, as discussed ahead) and gas bubbles (Figure 2a-c). Tin oxide is easily observed in every blue or white glaze, and also in some green and brown tin-opacified glazes, as previously mentioned. Tin oxide particles appear in very small agglomerates. As suggested 
by previous results for SCV tiles (Coentro et al., 2014), the small size and homogeneous distribution of tin oxide crystals in PNS (Figure 3) and IVDJ-S opaque glazes are consistent with a fritted glaze technology (Molera et al., 1997, 2001b; Vendrell-Saz et al., 2006).

IVDJ-S samples show morphological similarities with Portuguese (SCV and PNS) collections (Figure 2a-c). However, IVDJ-T samples show heterogeneous glazes, with mineral inclusions (mostly quartz) (Figure 2d). Such mineral inclusions were intentionally used in HispanoMoresque white glazes from Teruel (Pérez-Arantegui et al., 2005, 2009), as they contribute to the opacification of the glaze and lower the production costs by reducing the necessary amount of tin.

Blue glazes, in particular, have shown a similar composition in all three collections, displaying a $\mathrm{Fe}-\mathrm{Co}-\mathrm{Ni}$-Cu association. Some samples contain very low $\mathrm{Mn}$ contents as well. The Fe-Co-Ni$\mathrm{Cu}$ association has also been identified for Italian and Spanish ceramics from the $14^{\text {th }}-16^{\text {th }}$ centuries (Roldan et al., 2006).

Although this association of elements was identified for all SCV samples (Coentro et al., 2012), there are other combinations in PNS blue glazes, in particular with the identification of As:

- $\quad$ Fe-Co-Ni-Cu-As (PNS20)

- $\quad$ Fe-Co-Ni-As (PNS22)

- $\quad$ Fe-Co-Ni-As-Bi (PNS29)

The presence of As in the blue pigment composition has been identified in glasses and glazes dated from the end of the $15^{\text {th }}$ century onwards (Gratuze et al., 1997; Roldan et al., 2006; Zucchiati et al., 2006). These differences in cobalt associations do not necessarily mean that the pigment was imported from more than one location, since all the above mentioned cobalt associations existed in the mining district of Erzgebirge (Saxony), in Germany, which was the most important cobalt source at that time (Gratuze et al., 1997; Zucchiati et al., 2006; Roldan et al., 2006). Accordind to Zucchiati et al. (2006), the presence of arsenic from the $16^{\text {th }}$ century onwards could be associated with a change in the production of zaffre (calcinated cobalt ore, mixed with sand) which occurred in the Saxony region (Zucchiati et al., 2006). 
On the other hand, different sources for the cobalt pigment are still possible. The origin of the use of cobalt in the Iberian Peninsula comes from the Arab occupation and dates back at least since the $13^{\text {th }}$ century (Trindade, 2009). Cobalt deposits were known in the Morocco and Persian regions, from where several ceramists came to the Iberian Peninsula (Trindade, 2009).

\section{Green glazes}

Three main shades of green glazes were identified: a transparent dark green, an opaque tinopacified green and a turquoise green. The SCV collection stands out for only containing the first type of green glaze.

The compositions of the green "transparent" glazes identified in most arista and cuerda seca samples from all three collections, were found to comprise of $1-3 \mathrm{wt} . \% \mathrm{CuO}$ and $<2 \mathrm{wt} . \% \mathrm{SnO}_{2}$. This dark transparent type is the most common in Hispano-Moresque tiles.

The PNS and IVDJ collections contain tin-opacified green glazes, with $\mathrm{SnO}_{2}$ contents between 3-9 wt.\%. Glazes with $\mathrm{SnO}_{2}$ values above 7 wt.\%, exhibit a turquoise shade (PNS03, IVDJ 3561, 3794 and 3919) that is easily differentiated from the common dark green in the other tiles. Other tin-opacified greens with 3-4 wt.\% $\mathrm{SnO}_{2}$ were found in Spanish samples and a cuerda-seca PNS tile (PNS06, the armillary sphere).

In IVDJ 3561 turquoise glaze, malayaite, $\mathrm{CaSnO}\left(\mathrm{SiO}_{4}\right)$, was identified both by Synchrotron $\mu$ XRD (Figure 4) and $\mu$-Raman (Figure 5a). Malayaite was previously identified also in two SCV green glazes (Coentro et al., 2014). This calcium-tin silicate is formed through the reaction between the calcium and the tin in the glaze melt (Mulholland, 1984).

\section{Amber glazes}

In amber glazes, high $\mathrm{Fe}_{2} \mathrm{O}_{3}$ contents (2-5 wt.\%) were identified. When compared to the other colours, the $\mathrm{Fe}_{2} \mathrm{O}_{3} / \mathrm{SiO}_{2}$ ratio is considerably higher in amber glazes, which suggests the intentional addition of Fe compounds to obtain the colour.

Highest $\mathrm{Fe}_{2} \mathrm{O}_{3}$ contents are observed in SCV collection, mostly above 4 wt.\%, whereas in PNS and IVDJ amber glazes, $\mathrm{Fe}_{2} \mathrm{O}_{3}$ is almost always below this value. However, it is known that the 
chemical composition of the glaze is influenced by the reaction that occurs with the ceramic body during firing (Molera et al., 2001a). Thus, small differences in clay constituent oxides such as $\mathrm{Al}_{2} \mathrm{O}_{3}, \mathrm{CaO}$ and $\mathrm{Fe}_{2} \mathrm{O}_{3}$ can be related to the ceramic body composition and firing conditions, instead of a different glaze recipe.

\section{Brown glazes}

Brown manganese glazes appear as a dark colour with various shades, sometimes also referred to as "purple" or "black".

In PNS relief tiles, manganese was mixed with a white tin glaze, which results in an opaque lighter colour that is unique in this collection and in this group of tiles in particular. It is a different shade from the one observed in later majolica tiles, where the manganese pigment was applied on the glaze with a brush. In PNS relief tiles, manganese brown is a homogenous colour

Brown glazes display $\mathrm{MnO}$ contents between $2 \mathrm{wt} \%$ and $5 \mathrm{wt} . \%$. Manganese appears associated with higher contents of iron. Barium also appears associated with manganese in approximately half of the samples, which is frequent in manganese-brown decorations (Coentro et al., 2012, 2014; Molera et al., 2013) and has been attributed to the Ba-containing minerals (Ba-feldspars, psilomelane $\left.\left(\mathrm{Ba}, \mathrm{H}_{2} \mathrm{O}\right)_{2} \mathrm{Mn}_{5} \mathrm{O}_{10}\right)$ and barite $\left(\mathrm{BaSO}_{4}\right)$ ) abundant in manganese ore sources (Tite et al., 2009).

\section{Analysis of the glaze-ceramic interface}

Figure 6 illustrates the typical glaze and glaze-ceramic interface found in white and blue glazes. In PNS samples, the interface is generally thinner (ca. 30-70 $\mu \mathrm{m}$ ) than in SCV samples (ca. 30$100 \mu \mathrm{m})$ - the interface thickness is considered here as the layer with mineral inclusions that results from the reaction between the glaze and the ceramic body of the tile. Thicker interfaces (up to $100 \mu \mathrm{m}$ ) are visible in brown and amber glazes in all collections. When there is a stronger reaction between the glaze and the ceramic body, it originates a large number of small mineral inclusions that are spread through the glaze until reaching the surface. Interface thickness can be an indicator of firing technology, namely the number of firings. According to Molera et al. 
(2001a), a single fired object will present thicker interfaces $(>30 \mu \mathrm{m})$ than a double fired one (ca. $10 \mu \mathrm{m})$, due to the reaction between glaze and ceramic body, which is stronger when the latter is unfired. Studies on Islamic and Hispano-Moresque lead-glazed ceramics have indicated that a double-firing process was used in Islamic workshops, but it was progressively abandoned in Hispano-Moresque ones, as suggested by the study of $14^{\text {th }}-15^{\text {th }}$ century ceramic fragments from workshops in Paterna (Molera et al., 1997). However, Hispano-Moresque tin-glazed ceramics from Teruel, Spain, and also every coeval lustre-decorated ceramics from several Iberian production centres exhibit thinner interfaces $(<10 \mu \mathrm{m})$, consistent with a continuity of a doublefiring process (Molera 1997, 2001a; Pérez-Arantegui et al., 2005, 2009), but in these cases tiles exhibit a thicker glaze than tin-glazed wares, and thicker glazes develop thinner interfaces in single firing. In the particular case of Hispano-Moresque tiles, the results do not allow for determining whether one or two firings took place, as more data is needed for tin-glazed ceramics. It is also possible that the ceramic body was previously fired at a low temperature or that a slip was used to increase the adherence of the glaze onto the ceramic substrate. Chemical and phase analysis of the mineral inclusions in the interface (by SEM-EDS and $\mu$ Raman) revealed that it is mostly constituted of K-feldspars (orthoclase and microcline $\left.\mathrm{KAISi}_{3} \mathrm{O}_{8}\right)$ and, in some cases, of diopside crystals $\left(\mathrm{CaMgSi}_{2} \mathrm{O}_{6}\right)$ as well. Through $\mu$-Raman analysis, mostly orthoclase was identified in the glaze-ceramic interface of PNS and IVDJ samples, but also microcline, quartz $\left(\mathrm{SiO}_{2}\right)$, anatase $\left(\mathrm{TiO}_{2}\right)$ and, in sample IVDJ-T 3683, rutile $\left(\mathrm{TiO}_{2}\right)$. Wollastonite $\left(\mathrm{CaSiO}_{3}\right)$, which was widely detected in SCV samples (Coentro et al., 2014), also appears in some PNS samples. When comparing most SCV and PNS samples, a Ca-rich layer can be seen in the first ones, but a K-rich interface prevails in the later, as Figure 6 illustrates. This is one of the main differences between these collections. In the four IVDJ-S samples analysed by SEM-EDS, both potassium and calcium-rich inclusions show up in EDS maps. In the three IVDJ-T analysed samples, a K-rich interface appears in all of them. The presence of diopside indicates firing temperatures above $900^{\circ} \mathrm{C}$, when it is formed, most likely as a reaction product from magnesium-rich minerals, such as dolomite $\left(\mathrm{CaMg}\left(\mathrm{CO}_{3}\right)_{2}\right)$ and silicates. The identification of rutile could be an indicator of still higher firing temperature $(>1000$ 
$\left.{ }^{\circ} \mathrm{C}\right)$, but it is known that it could also be related with the raw ceramic material. Therefore, it should not be used here as a temperature marker (Ricciardi 2008).

Synchrotron $\mu$-XRD analysis of IVDJ samples also identified sanidine crystals in the glazeceramic interface (Figure 4). These crystals can incorporate $\mathrm{Pb}$ ions in their structure during firing. The formation of $\mathrm{Pb}$-sanidine crystals is promoted by the high-temperature reaction $\left(800^{\circ} \mathrm{C}-1000^{\circ} \mathrm{C}\right)$ between lead-rich glazes and potassium-rich ceramic bodies and has been widely identified in Hispano-Moresque lead glazes (Molera et al., 1993; Pradell et al., 2010). Lead was also identified in a lead-aluminium silicate $\left(\mathrm{PbAl}_{2} \mathrm{Si}_{2} \mathrm{O}_{8}\right)$. It is expected that lead reacts with silicates in the glaze and the ceramic body of the tiles, due to the high contents of this element in the glaze composition.

The glaze-ceramic interface in brown glazes consistently shows Ca-Mn-rich inclusions and their acicular shapes suggest the presence of bustamite $\left(\mathrm{CaMnSi}_{2} \mathrm{O}_{6}\right)$, as identified by $\mu$-Raman in sample PNS07 (Figure 5b). Bustamite, a Mn-pyroxene, is most likely formed from the reaction between the manganese in the glaze melt and the calcium, mostly from the ceramic paste, at temperatures above $950 \stackrel{\circ}{\circ}$ (Molera et al., 2013). Hausmannite $\left(\mathrm{Mn}_{3} \mathrm{O}_{4}\right)$, which was identified in SCV samples (Coentro et al., 2014) and suggests slightly higher temperatures (ca. $1000^{\circ} \mathrm{C}$ ) (Molera et al., 2013), could not be identified in the collections from Sintra and Spain. Kentrolite $\left(\mathrm{Pb}_{2} \mathrm{Mn}_{2} \mathrm{Si}_{2} \mathrm{O}_{9}\right)$ was identified in one Spanish sample (brown glaze in IVDJ 4095 - Toledo) (Figure $5 \mathrm{c}$ and $5 \mathrm{~d}$ ). It was likely formed through the reaction between the manganese and the silica-lead glaze matrix. The presence of kentrolite suggests lower firing temperatures, since this compound is stable between approximately $650^{\circ} \mathrm{C}$ and $840^{\circ} \mathrm{C}$ (Molera et al., 2013).

\section{CONCLUSIONS}

The analysis and comparison of three different collections of Hispano-Moresque glazed tiles revealed a similar technological background for the production of the glazes. Quantitative results obtained by $\mu$-PIXE show similar overall chemical compositions amongst all collections, even when comparing samples from different known provenances, such as the ones from 
Toledo and from Seville (Instituto Valencia de Don Juan, Madrid). This is consistent with the existence of a widespread technology in the Iberian Peninsula and its usage in several production centres.

Hispano-Moresque tiles were decorated with high-lead glazes, which were coloured with $\mathrm{Cu}$ (green), Co (blue), Mn (brown) and Fe (amber) oxides. White and blue glazes were always opacified with $\mathrm{SnO}_{2}$, but the other colours appear both with and without tin in their composition this results in more variety of hues (i.e. dark green, light green, turquoise). Such variety is present in PNS and IVDJ samples, but not in the SCV collection. Colorant oxides are completely dissolved in the glaze matrix and few bubbles and inclusions are observed, which suggests that glaze frits were prepared for obtaining the different coloured glazes. Glaze compositions also suggest that two different base recipes were used: one for a tin-opacified glaze and another for a transparent lead glaze, the latter containing more $\mathrm{PbO}$ and less $\mathrm{SiO}_{2}$ and $\mathrm{Na}_{2} \mathrm{O}$ in its composition.

In spite of the overall compositional similitude found, the SCV collection differs from the others: it shows higher dispersion in $\mathrm{SnO}_{2}$ contents (with samples containing $>10 \mathrm{wt} . \% \mathrm{SnO}_{2}$ ), higher $\mathrm{Fe}_{2} \mathrm{O}_{3}$ contents in the amber glaze and a Ca-rich layer in the glaze-ceramic interface. Unfortunately however, these data are not yet sufficient to confirm or discard a possible local production for this collection. At present this is as much a valid hypothesis as these tiles having been imported from a different production centre, either the same or different ones from the Sevillian tiles.

Adding to this variability, the IVDJ-T glazes are morphologically different from the others, due to the number of inclusions they contain.

In the PNS collection the relief tiles show a different glazing technology and have no parallel in the literature. The results suggest a sort of "pre-majolica" technique, with the use of a white tinlead glaze as a base for all colours, with the pigment and white tin ground concentrations unevenly distributed, resulting in colour variations. Here, these marked and unique differences strongly suggest a different, possibly local, provenance. These tiles will be the subject of a specific study. 


\section{ACKNOWLEDGEMENTS}

The authors would like to acknowledge Fundação para a Ciência e Tecnologia (FCT) for a Ph.D. grant SFRH/BD/73007/2010 (S. Coentro), a BI Mestre grant PTDC/CPC-EAT/4719/2012 (C. Relvas), research project PTDC/CPC-EAT/4719/2012 and research units UID/EAT/00729/2013 and UID/Multi/04349/2013. The authors also acknowledge financial support through LARES (ALENT-07-0224-FEDER-001761) and MICRA.Lab projects (ALENT07-0262-FEDER-001868) INALENTEJO/QREN/FEDER funding. The authors would also like to thank Dr. Elisa Ramiro and Dr. Cristina Partearroyo from the Instituto Valencia de Don Juan, Madrid, for allowing the sampling and the many insightful conversations on Hispano-Moresque tiles, Luis Dias from HERCULES laboratory for the SEM-EDS analysis, Dr. Inês Ferro, Dr. Joana Amaral and Dr. Rita Dargent from Palácio Nacional de Sintra, and Dr. Artur Côrte-Real and Dr. Catarina Leal from Mosteiro de Santa Clara-a-Velha.

\section{REFERENCES}

Barros, I., Cardoso, G., Gonçalves, A., 1999, Primeira notícia do forno de S. António da Charneca - Barreiro, Actas das $3^{\text {as }}$ Jornadas de cerâmica medieval e pós-medieval, pp. 295-307 (in Portuguese; abstract also in French)

Brill, R. H., 1999. Chemical Analysis of Early Glasses. Corning, New York: The Corning Museum of Glass.

Campbell, J.L., Boyd, N.I., Grassi, N., Bonnick, P., Maxwell, J.A., 2010. The Guelph PIXE software package IV. Nuclear Instruments and Methods B, 268, 3356-3363 
Coentro, S., Mimoso, J.M., Lima, A.M., Silva, A.S., Pais, A.N., Muralha, V.S.F., 2012. Multianalytical identification of pigments and pigment mixtures used in 17th century Portuguese azulejos. Journal of the European Ceramic Society, 32 (1), 37-48.

Coentro, S., Trindade, R.A.A., Mirão, J., Candeias, A., Alves, L.C., Silva, R.M.C., Muralha, V.S.F., Hispano-Moresque ceramic tiles from the Monastery of Santa Clara-a-Velha (Coimbra, Portugal), Journal of Archaeological Science, Volume 41, 2014, 21-28

Chabanne, D., Bouquillon, A., Aucouturier, M., Dectot, X., Padeletti, G., 2008, Physico-chemical analyses of Hispano-Moresque lustred ceramic: a precursor for Italian majolica?, Applied Physics A, 92, 1, 11-18

Côrte-Real, A., Leal, C., Munhós, M., Macedo, F.P., Bernardo, L., Ferreira, M.A., Santos, P.C., 2010. O Mosteiro de Santa Clara-a-Velha de Coimbra: investigação, musealização e síntese de aspectos orientalizantes no espólio, In: Actas do IV Congresso de Arqueologia Penínsular: As idades medieval e moderna na Península Ibérica, Faro, pp. 113-128.

Gratuze, B., Soulier,I., Blet, M., Vallauri, L., 1997, De l'origine du cobalt: du verre à la céramique, Revue d'archéométrie 20, 1, 77-94

Grime, G.W., Dawson, M., 1995. Recent developments in data acquisition and processing on the Oxford scanning proton microprobe. Nuclear Instruments and Methods B, 104, 107-113 J. Molera, T. Pradell, S. Martinez-Manent, M. Vendrell-Saz, 1993, The growth of sanidine crystals in the lead glazes of Hispano-Moresque pottery, Applied Clay Science, 7, 483-491 
Molera, J., Pradell, T., Merino, L., García-Vallés, M., García-Orellana, J., Salvadó, N., VendrellSaz, M., 1997. La tecnología de la cerámica Islámica y Mudéjar. Caesaraugusta, 73, 15-41.

Molera, J., Pradell, T., Vendrell-Saz, M., 1998, The colours of Ca-rich ceramic pastes: origin and characterisation. Applied Clay Science, 13, 187-202

Molera, J., Pradell, T., Salvadó, N., Vendrell-Saz, M., 2001a. Interactions between Clay Bodies and Lead Glazes. Journal of the American Ceramic Society, 84 (5), 1120-28.

Molera, J., Vendrell-Saz, M., Pérez-Arantegui, J., 2001b. Chemical and Textural Characterization of Tin Glazes in Islamic Ceramics from Eastern Spain. Journal of Archaeological Science, 28, 331-340.

Molera, J., Pradell, T., Salvadó, N., Vendrell-Saz, M., 2009. Lead frits in Islamic and HispanoMoresque glazed productions. In: Shortland, A., Freestone, I.C., Rehren, T. (Eds), From Mine to Microscope: Advances in the Study of Ancient Technology, Oxbow Books, Oxford, Chapter 1, pp. 1-10.

Molera, J., Coll, J., Labrador, A., Pradell, T., 2013, Manganese brown decorations in 10th to 18th century Spanish tin glazed ceramics, Applied Clay Science, 82, 86-90

Mulholland, I.R., 1984. Malayaite and tin-bearing garnet from a skarn at Gumble, NSW, Australia. Mineralogical Magazine 48, 27-30.

L. Ortega, M. Cruz Zuluaga, A. Alonso-Olazabal, J.J. Bienes, J.L. Solaun, 2012, Production and technological evolution from Islamic to Christian glazed pottery during $11^{\text {th }}$ to $16^{\text {th }}$ centuries, Macla, 16, 36-37. 
Pérez-Arantegui, J., Ortega, J.M., Escriche. C., 2005. La tecnología de la cerámica Mudéjar entre los siglos XIV y XVI: las producciones esmaltadas de las zonas de Teruel y Zaragoza. In: VI Congreso Ibérico de Arqueometría: Avances en Arqueometría, pp. 89-96.

Pérez-Arantegui, J., Ortega, J., Escriche, C., 2009, The Hispano-Moresque tin glazed ceramics produced in Teruel, Spain: a technology between two historical periods, 13th to 16th c. AD, in: "From Mine to Microscope: Advances in the Study of Ancient Technology", lan Freestone and Thilo Rehren [Ed], Oxbow Books

Pradell, T., Molera, J., Salvadó, N., Labrador, A., 2010. Synchrotron radiation micro-XRD in the study of glaze technology. Applied Physics A, 99, 407-417.

Ricciardi, P., Raman spectroscopy for the non-destructive characterization of ancient pottery, porcelains and mosaic glasses, Università degli studi di Firenze, 2008.

Roldán, C., Coll, J., Ferrero, J., 2006. EDXRF analysis of blue pigments used in Valencian ceramics from the 14th century to modern times. Journal of Cultural Heritage, 7, 134-138.

RRUFF Project Database. [http://rruff.info/] (accessed 15-12-2014)

Tite, M.S., Maniatis, Y., Kavoussanaki, D., Panagiotaki, M., Shortland, A.J., Kirk, S.F., 2009. Colour in Minoan faience. Journal of Archaeological Science, 36, 370-8. 
Trindade, R.A.A., 2008. Revestimentos Cerâmicos Portugueses. Meados do século XIV à primeira metade do século XVI. Edições Colibri/Faculdade de Ciências Sociais e Humanas da Universidade Nova de Lisboa, Lisboa.

Vendrell-Saz, M., Molera, J., Roqué, J., Pérez-Arantegui, J., 2006. Islamic and HispanoMoresque (múdejar) lead glazes in Spain: a technical approach. In: Maggetti, M., Messiga, B. (Eds.), Geomaterials in Cultural Heritage. The Geological Society of London, London, pp. 163173

Vieira Ferreira L. F., Conceição D. S., Ferreira D. P., Santos L. F., Casimiro T. M., Ferreira Machado I. 2014, Portuguese 16th century tiles from Santo António da Charneca's kiln: a spectroscopic characterization of pigments, glazes and pastes, Journal of Raman Spectroscopy, 45, 838-847

Zucchiatti, A., Bouquillon, A., Katona, I., D’Alessandro, A., 2006. The 'Della Robbia blue': a case study for the use of cobalt pigments in ceramics during the Italian Renaissance. Archaeometry, 48 (1), 131-152 

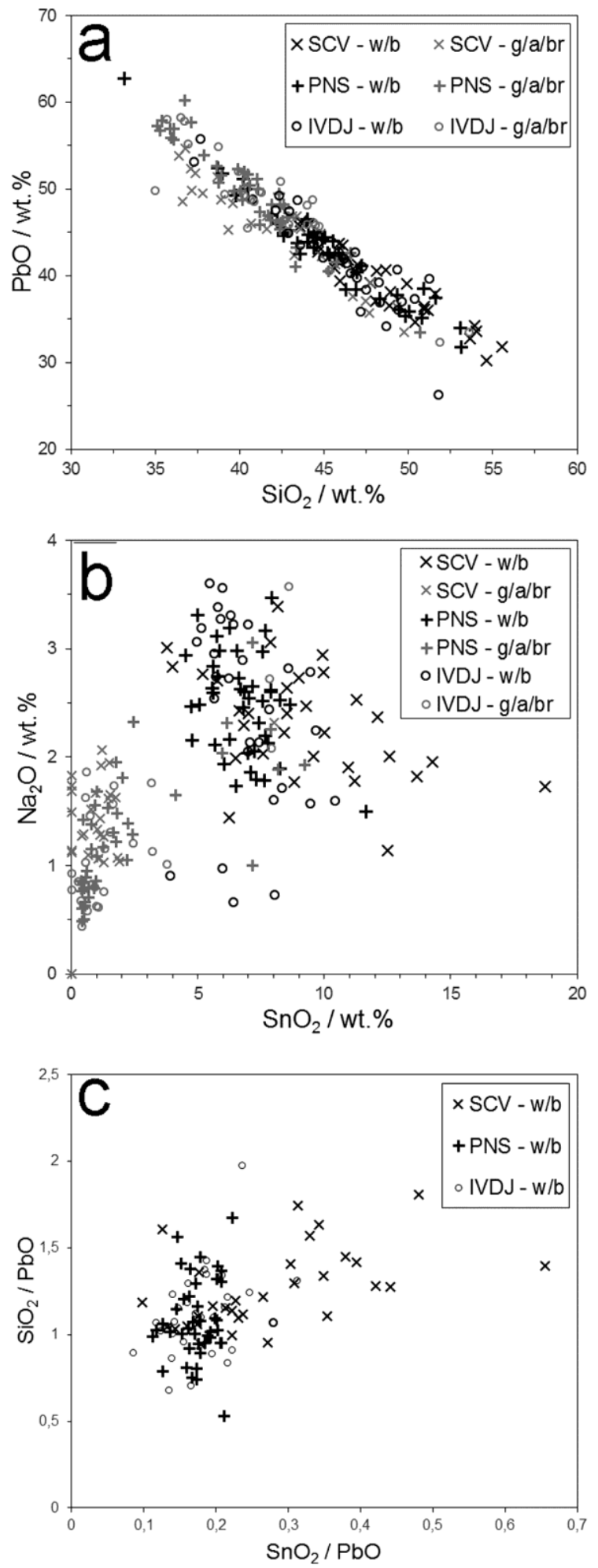

Figure 1 - Binary plots obtained through $\mu$-PIXE analysis: (a) $\mathrm{SiO}_{2}$ vs. $\mathrm{PbO}$ (wt.\%), where an inverse correlation can be seen, with white and blue glazes showing higher $\mathrm{SiO}_{2}$ and lower $\mathrm{PbO}$ contents; (b) $\mathrm{SnO}_{2}$ vs. $\mathrm{Na}_{2} \mathrm{O}$ (wt.\%), where tin-opacified glazes (mostly white and blue) are associated with higher $\mathrm{Na}_{2} \mathrm{O}$ contents; (c) $\mathrm{SnO}_{2} / \mathrm{PbO}$ vs. $\mathrm{SiO}_{2} / \mathrm{PbO}$, where SCV samples stand out for their higher $\mathrm{SnO}_{2} / \mathrm{PbO}$ ratios. 

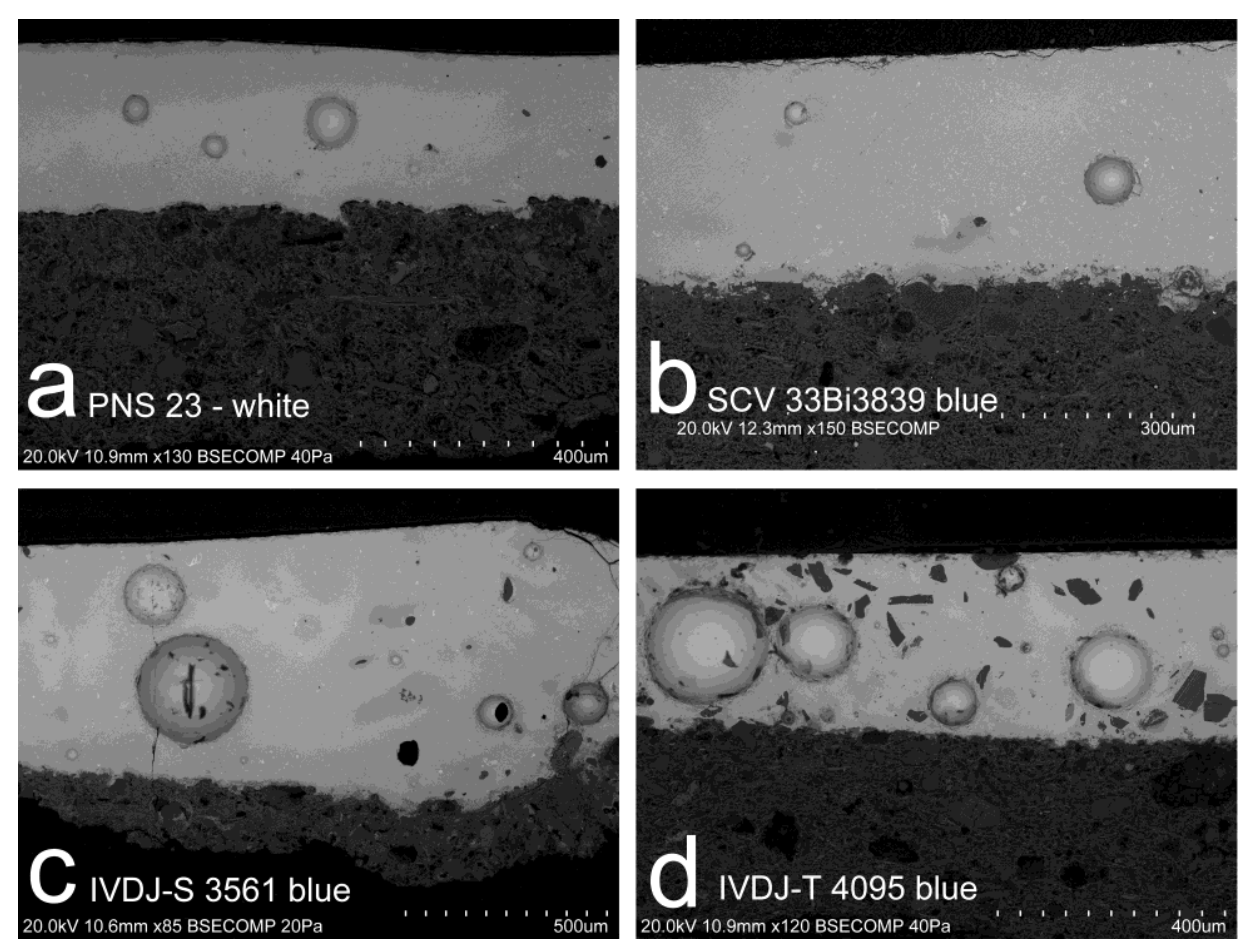

Figure 2 - BSE images of four white and blue glazes in cross-section: 2a) PNS; 2b) SCV; 2c) IVDJ-S (attributed) and 2d) IVDJ-T (attributed).
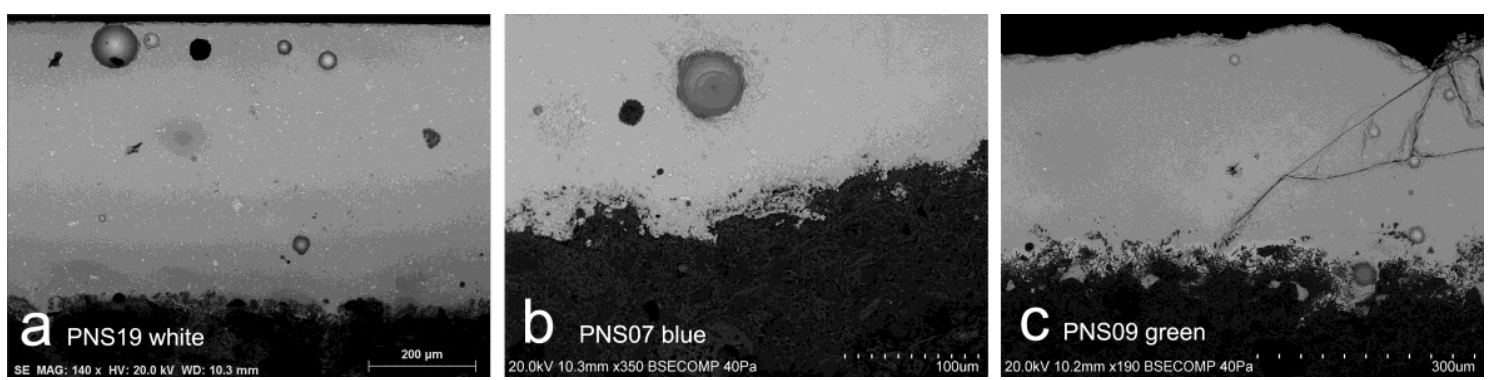

Figure 3 - BSE images of tin-opacified PNS glazes in cross-section: small tin oxide agglomerates homogenously distributed throughout the white glaze of a cuerda-seca tile (3a), and the blue $(3 b)$ and green $(3 c)$ glaze in relief tiles. 


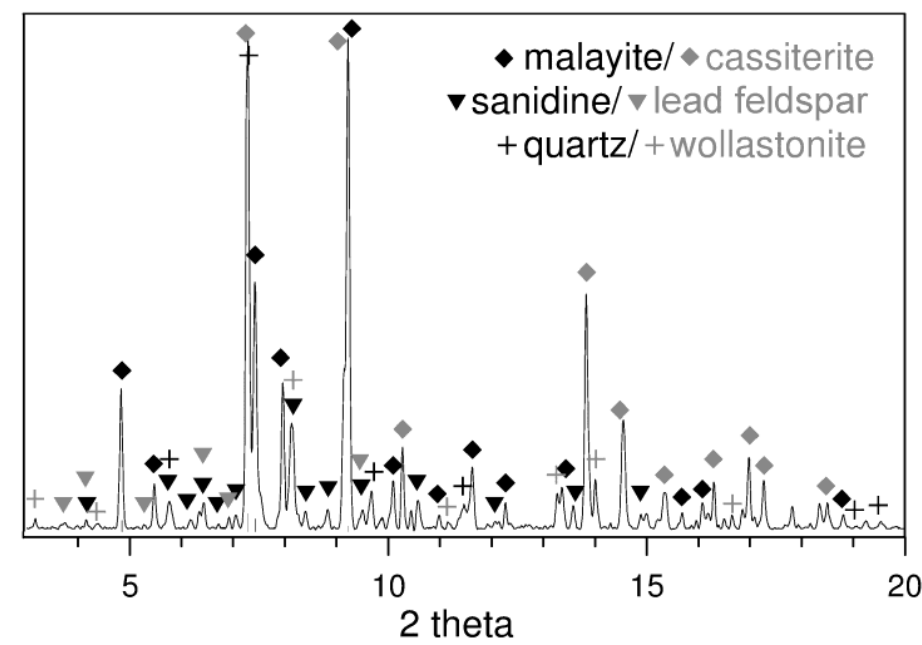

Figure 4 - Difractrogram of turquoise green glaze, near the interface of sample IVDJ 3561-S, where malayaite, cassiterite, sanidine / lead feldspar, quartz and wollastonite were identified.
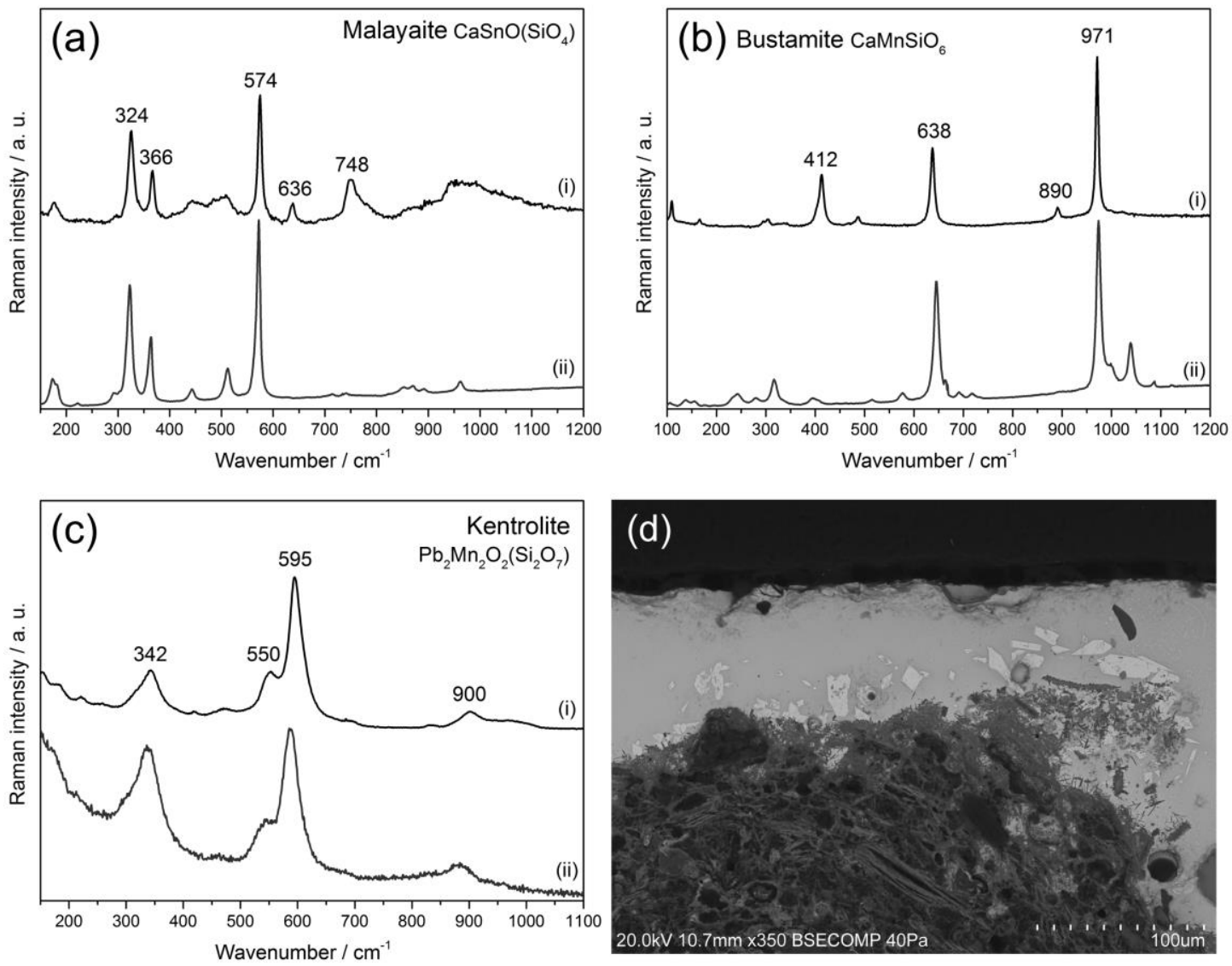

Figure 5 - $\mu$-Raman spectrum of (a) malayaite - IVDJ-S 3561 (i) and reference spectrum (ii); (b) bustamite - PNS07 (i) and reference spectrum (ii); (c) kentrolite - IVDJ 4095-T (i) and reference spectrum (ii). BSE image (d) shows kentrolite crystals in the brown glaze of sample 4095-T. These crystals appear whiter due to $\mathrm{Pb}$ in their composition. 

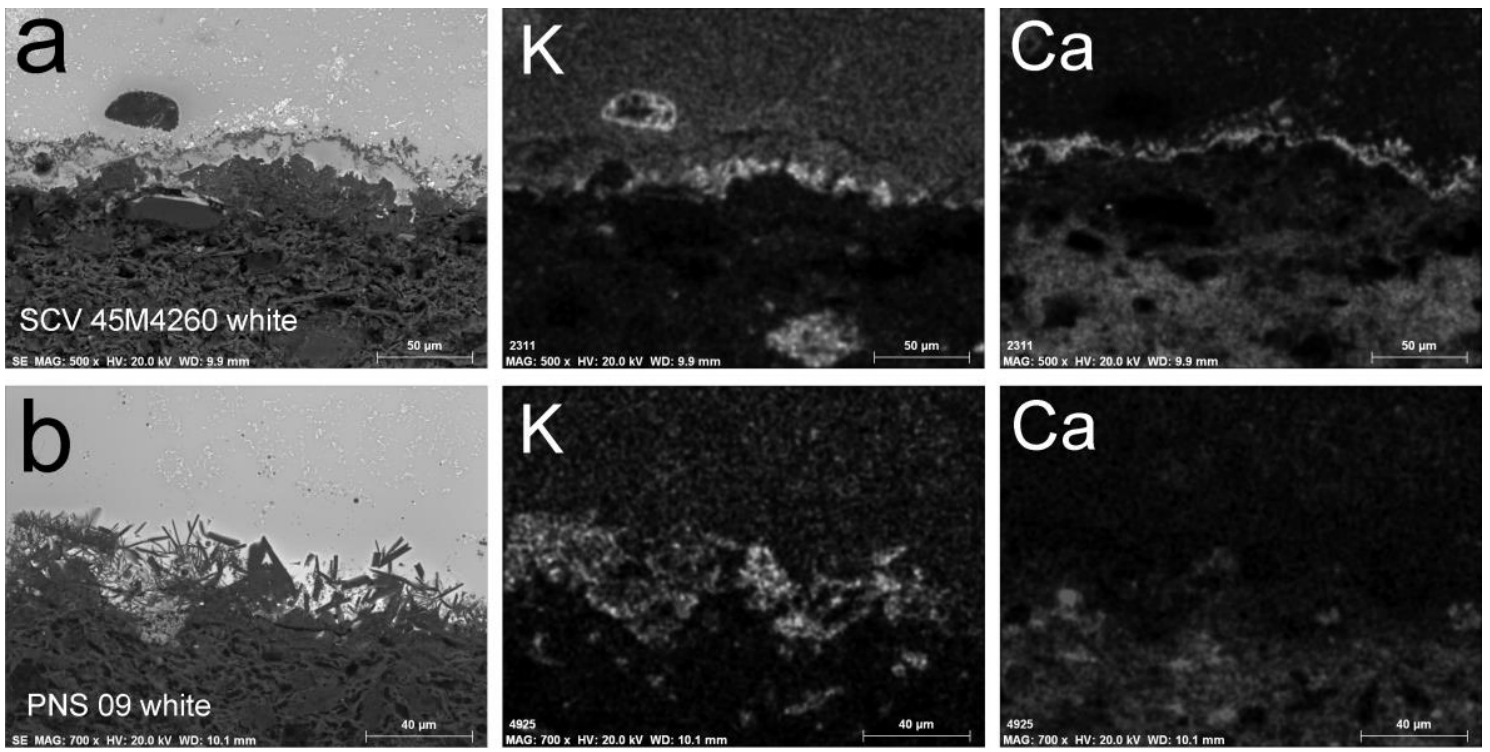

Figure 6 - EDS X-ray maps, comparing SCV (a) and PNS (b) glaze-ceramic interfaces. A Carich layer, absent in PNS sample (b), is observed in the SCV one (a).
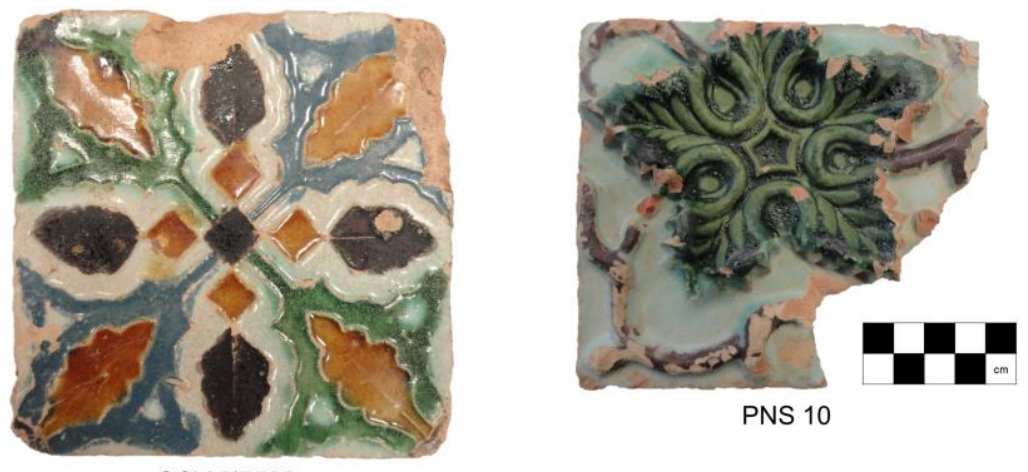

SCV $8 i 7532$

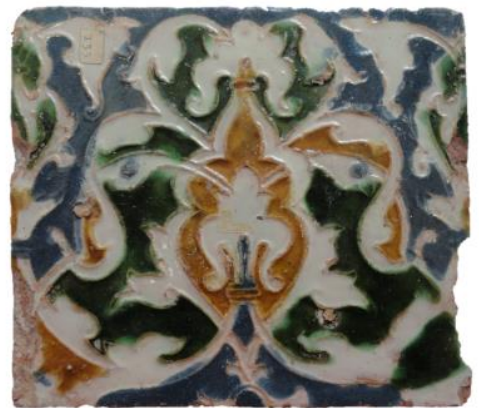

IVDJ-T 133

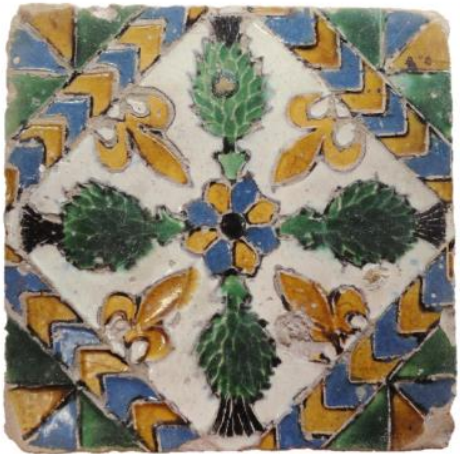

IVDJ-S 4107

Figure S1 - Samples from each studied collection. 
Table 1 - $\mu$-PIXE values obtained for the glass standards Corning Museum of Glass (CMoG) B and C. Certified values obtained in Brill (1999).

Table 2 - Average chemical composition (in wt.\%) of the analysed tiles from PNS, SCV and IVDJ collections, obtained by $\mu$-PIXE. Results are divided by colour and technique ( $A$ arista, $C S$ cuerda seca, $R$ relief, $F$ flat).

Table S1 - Chemical composition (in wt.\%) of the analysed tiles from PNS, SCV and IVDJ collections, obtained by $\mu$-PIXE. Results are divided by colour. Techniques: $A$ arista, $C S$ cuerda seca, $R$ relief, $F$ flat. 
Table 1 - $\mu$-PIXE values obtained for the glass standards Corning Museum of Glass (CMoG) B and C. Certified values obtained in Brill (1999).

\begin{tabular}{|c|c|c|c|c|c|c|c|c|c|c|c|c|c|c|}
\hline Glass standards & $\mathrm{Na}_{2} \mathrm{O}$ & MgO & $\mathrm{Al}_{2} \mathrm{O}_{3}$ & $\mathrm{SiO}_{2}$ & $\mathrm{~K}_{2} \mathrm{O}$ & $\mathrm{CaO}$ & $\mathrm{TiO}_{2}$ & MnO & $\mathrm{Fe}_{2} \mathrm{O}_{3}$ & $\mathrm{CoO}$ & $\mathrm{NiO}$ & CuO & $\mathrm{BaO}$ & PbO \\
\hline \multicolumn{15}{|l|}{ CMoG B } \\
\hline Certified (wt.\%) & 17 & 1.03 & 4.36 & 62.27 & 1 & 8.56 & 0.089 & 0.25 & 0.34 & 0.046 & 0.099 & 2.66 & 0.12 & 0.61 \\
\hline Measured (wt.\%) & 17.1 & 0.96 & 4.3 & 64.8 & 0.96 & 7.5 & 0.12 & 0.22 & 0.30 & 0.08 & 0.10 & 2.3 & 0.10 & 0.43 \\
\hline SD (wt.\%) & 1.2 & 0.05 & 0.3 & 1.0 & 0.05 & 0.4 & 0.02 & 0.04 & 0.03 & 0.03 & 0.02 & 0.2 & 0.04 & 0.13 \\
\hline \multicolumn{15}{|l|}{ CMoG C } \\
\hline Certified (wt.\%) & 1.07 & 2.76 & 0.87 & 34.3 & 2.84 & 5.07 & 0.79 & - & 0.34 & 0.18 & - & 1.13 & 11.4 & 36.7 \\
\hline Measured (wt.\%) & 1.14 & 2.4 & 0.89 & 35.8 & 2.60 & 4.42 & 0.6 & - & 0.30 & 0.16 & - & 1.09 & 11.5 & 38.8 \\
\hline SD (wt.\%) & 0.09 & 0.1 & 0.04 & 1.3 & 0.06 & 0.08 & 0.1 & & 0.02 & 0.03 & & 0.06 & 0.2 & 1.8 \\
\hline
\end{tabular}

$S D$ - standard deviation 
$\begin{array}{lllllllllllllllll}\text { Technique } & \mathrm{Na}_{2} \mathrm{O} & \mathrm{MgO} & \mathrm{Al}_{2} \mathrm{O}_{3} & \mathrm{SiO}_{2} & \mathrm{Cl} & \mathrm{K}_{2} \mathrm{O} & \mathrm{CaO} & \mathrm{TiO}_{2} & \mathrm{MnO} & \mathrm{Fe}_{2} \mathrm{O}_{3} & \mathrm{CoO} & \mathrm{NiO} & \mathrm{CuO} & \mathrm{SnO}_{2} & \mathrm{BaO} & \mathrm{PbO}\end{array}$

\begin{tabular}{|c|c|c|c|c|c|c|c|c|c|c|c|c|c|c|c|c|}
\hline \multirow{17}{*}{ 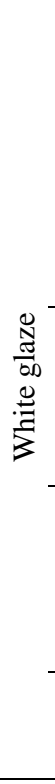 } & & F (PNS 04) & 1.49 & 0.29 & 0.42 & 29.2 & 0.98 & 0.21 & 0.28 & & & 0.21 & & & 11.65 & 55.3 \\
\hline & & $\mathrm{CS}(\mathrm{N}=9)$ & 2.35 & 0.51 & 1.87 & 40.8 & 0.76 & 2.72 & 1.97 & 0.12 & & 0.47 & & 0.15 & 6.90 & 41.5 \\
\hline & \multirow{5}{*}{ PNS } & \pm & 0.46 & 0.14 & 0.52 & 2.7 & 0.15 & 0.83 & 0.51 & 0.03 & & 0.15 & & 0.05 & 1.13 & 3.8 \\
\hline & & $\mathrm{R}(\mathrm{N}=10)$ & 2.41 & 0.46 & 1.69 & 40.2 & 0.82 & 2.75 & 2.08 & 0.14 & 0.11 & 0.46 & & 0.18 & 7.48 & 41.5 \\
\hline & & \pm & 0.61 & 0.21 & 0.54 & 4.3 & 0.36 & 0.53 & 0.95 & 0.06 & 0.05 & 0.20 & & 0.09 & 0.68 & 5.3 \\
\hline & & $A(N=6)$ & 2.55 & 0.61 & 2.57 & 44.0 & 0.70 & 2.24 & 2.63 & 0.15 & & 0.63 & & & 6.26 & 37.7 \\
\hline & & \pm & 0.24 & 0.17 & 0.64 & 2.4 & 0.28 & 0.90 & 0.73 & 0.03 & & 0.15 & & & 1.15 & 3.6 \\
\hline & \multirow{4}{*}{ SCV } & $\mathrm{CS}(\mathrm{N}=7)$ & 2.22 & 0.71 & 2.48 & 45.2 & 0.38 & 2.78 & 2.34 & 0.14 & 0.04 & 0.65 & & 0.12 & 8.13 & 34.9 \\
\hline & & \pm & 0.62 & 0.25 & 1.06 & 3.9 & 0.15 & 0.78 & 0.66 & 0.03 & 0.01 & 0.18 & & 0.06 & 2.67 & 6.0 \\
\hline & & $\mathrm{A}(\mathrm{N}=7)$ & 2.11 & 0.89 & 2.71 & 43.6 & 0.37 & 2.65 & 2.51 & 0.13 & & 0.65 & & 0.28 & 9.13 & 35.1 \\
\hline & & \pm & 0.50 & 0.55 & 0.25 & 4.1 & 0.18 & 0.99 & 1.13 & 0.06 & & 0.29 & & 0.25 & 2.95 & 4.3 \\
\hline & \multirow{4}{*}{ IVDJ-S } & $\mathrm{CS}(\mathrm{N}=8)$ & 2.43 & 0.50 & 2.42 & 40.2 & 0.59 & 1.93 & 2.12 & 0.12 & 0.09 & 0.52 & & 0.08 & 7.15 & 42.0 \\
\hline & & \pm & 0.61 & 0.15 & 1.14 & 4.2 & 0.32 & 0.90 & 0.87 & 0.04 & 0.05 & 0.17 & & 0.01 & 1.98 & 5.3 \\
\hline & & $\mathrm{A}(\mathrm{N}=5)$ & 2.44 & 0.79 & 2.88 & 42.2 & 0.28 & 2.23 & 3.27 & 0.13 & & 0.64 & & 0.06 & 7.78 & 37.3 \\
\hline & & \pm & 0.65 & 0.20 & 0.68 & 3.3 & 0.12 & 0.95 & 1.51 & 0.04 & & 0.16 & & 0.02 & 1.37 & 4.6 \\
\hline & \multirow{2}{*}{ IVDJ-T } & A (IVDJ-T 133) & 0.97 & 0.42 & 4.27 & 47.9 & 0.22 & 1.66 & 0.96 & 0.08 & & 0.41 & & 0.05 & 5.99 & 37.0 \\
\hline & & A (IVDJ-T 3683) & 0.73 & 0.61 & 3.59 & 45.2 & 0.30 & 2.12 & 1.70 & 0.08 & & 0.31 & & & 8.05 & 37.3 \\
\hline \multirow{19}{*}{ 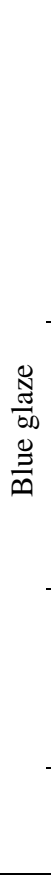 } & \multirow{7}{*}{ PNS } & F (PNS 01) & 3.16 & 0.41 & 1.61 & 35.6 & 0.58 & 2.20 & 1.73 & 0.11 & 0.09 & 1.77 & $0.43 \quad 0.19$ & 0.24 & 7.67 & 44.2 \\
\hline & & $\mathrm{CS}(\mathrm{N}=7)$ & 2.59 & 0.50 & 2.14 & 42.8 & 0.81 & 3.09 & 2.46 & 0.12 & 0.04 & 1.47 & $0.37 \quad 0.20$ & 0.25 & 6.20 & 36.7 \\
\hline & & \pm & 0.51 & 0.10 & 0.49 & 2.8 & 0.29 & 1.02 & 0.61 & 0.02 & 0.01 & 0.20 & $0.06 \quad 0.09$ & 0.11 & 0.78 & 3.8 \\
\hline & & $\mathrm{R}(\mathrm{N}=3)$ & 2.60 & 0.57 & 2.13 & 40.1 & 0.43 & 3.04 & 2.94 & 0.15 & 0.09 & 1.84 & $0.38 \quad 0.18$ & 0.33 & 7.17 & 38.0 \\
\hline & & \pm & 0.34 & 0.14 & 0.37 & 3.5 & 0.01 & 0.73 & 0.71 & 0.03 & 0.08 & 0.17 & 0.04 & 0.11 & 1.22 & 3.4 \\
\hline & & $\mathrm{A}(\mathrm{N}=6)$ & 2.42 & 0.72 & 2.34 & 44.0 & 0.55 & 2.14 & 2.70 & 0.13 & & 1.26 & $0.33 \quad 0.16$ & 0.15 & 5.92 & 36.2 \\
\hline & & \pm & 0.37 & 0.14 & 0.48 & 4.0 & 0.19 & 0.65 & 0.73 & 0.02 & & 0.53 & 0.12 & 0.06 & 1.25 & 4.3 \\
\hline & \multirow{6}{*}{ SCV } & F (SCV 86i4886) & 2.53 & 0.72 & 2.22 & 43.2 & 0.35 & 3.73 & 3.15 & 0.12 & 0.02 & 2.09 & $0.42 \quad 0.11$ & 0.05 & 11.27 & 29.7 \\
\hline & & $\mathrm{CS}(\mathrm{N}=6)$ & 2.64 & 0.58 & 2.07 & 43.2 & 0.38 & 2.45 & 2.14 & 0.18 & 0.04 & 1.34 & $0.33 \quad 0.18$ & 0.31 & 9.45 & 34.7 \\
\hline & & \pm & 0.59 & 0.12 & 0.45 & 2.8 & 0.32 & 0.51 & 0.29 & 0.11 & 0.02 & 0.44 & $0.14 \quad 0.06$ & 0.11 & 5.05 & 4.4 \\
\hline & & R (SCV 14CF2686) & 2.01 & 0.78 & 2.19 & 39.4 & 0.23 & 1.97 & 2.65 & 0.15 & & 1.51 & $0.30 \quad 0.21$ & 0.45 & 12.56 & 35.6 \\
\hline & & $A(N=9)$ & 2.35 & 0.67 & 2.24 & 41.6 & 0.33 & 2.68 & 2.70 & 0.14 & 0.06 & 1.76 & $0.44 \quad 0.19$ & 0.34 & 9.29 & 35.2 \\
\hline & & \pm & 0.36 & 0.10 & 0.33 & 1.6 & 0.14 & 0.74 & 0.44 & 0.02 & 0.05 & 0.33 & 0.09 & 0.26 & 2.70 & 3.5 \\
\hline & \multirow{4}{*}{ IVDJ-S } & $\mathrm{CS}(\mathrm{N}=4)$ & 3.10 & 0.42 & 2.13 & 41.9 & 0.66 & 2.35 & 2.01 & 0.11 & 0.04 & 1.61 & $0.45 \quad 0.20$ & 0.25 & 6.01 & 38.8 \\
\hline & & \pm & 0.28 & 0.17 & 0.48 & 2.8 & 0.18 & 0.71 & 0.74 & 0.02 & 0.01 & 0.42 & 0.15 & 0.10 & 0.86 & 4.9 \\
\hline & & $\mathrm{A}(\mathrm{N}=8)$ & 2.83 & 0.80 & 3.00 & 41.8 & 0.46 & 2.56 & 3.03 & 0.16 & 0.05 & 2.31 & $0.64 \quad 0.27$ & 0.32 & 7.06 & 34.8 \\
\hline & & \pm & 0.72 & 0.37 & 0.86 & 2.7 & 0.32 & 0.98 & 1.67 & 0.04 & 0.02 & 1.12 & $0.39 \quad 0.18$ & 0.31 & 1.38 & 6.3 \\
\hline & \multirow{2}{*}{ IVDJ-T } & $\mathrm{A}(\mathrm{N}=3)$ & 2.09 & 0.72 & 3.86 & 42.8 & 0.68 & 2.11 & 1.70 & 0.10 & 0.06 & 1.03 & $0.29 \quad 0.15$ & 0.22 & 4.95 & 39.6 \\
\hline & & \pm & 2.27 & 0.30 & 0.57 & 3.1 & 0.52 & 0.87 & 1.09 & 0.01 & 0.08 & 0.57 & 0.03 & 0.13 & 1.31 & 6.0 \\
\hline \multirow{19}{*}{ 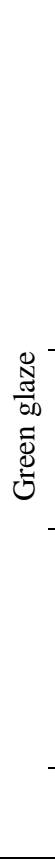 } & \multirow{8}{*}{ PNS } & $\mathrm{F}$ (PNS 02) & 1.17 & 0.69 & 3.03 & 38.6 & 0.21 & 2.01 & 3.38 & 0.18 & & 0.80 & & 1.94 & 1.26 & 46.8 \\
\hline & & F (PNS 03) & 1.00 & 0.12 & 0.57 & 32.9 & 0.36 & 0.30 & 0.37 & & & 0.27 & & 2.98 & 7.17 & 54.0 \\
\hline & & $\mathrm{CS}(\mathrm{N}=6)$ & 1.53 & 0.48 & 2.78 & 40.7 & 0.33 & 2.42 & 2.44 & 0.21 & 0.17 & 0.90 & & 1.68 & 2.23 & 44.3 \\
\hline & & \pm & 0.18 & 0.18 & 0.81 & 2.8 & 0.06 & 0.73 & 0.83 & 0.10 & 0.17 & 0.29 & & 0.50 & 0.97 & 4.4 \\
\hline & & $\mathrm{R}(\mathrm{N}=6)$ & 1.57 & 0.46 & 1.93 & 36.3 & 0.48 & 1.91 & 2.57 & 0.12 & & 0.77 & & 2.99 & 2.93 & 48.1 \\
\hline & & \pm & 0.91 & 0.10 & 0.48 & 2.2 & 0.18 & 0.75 & 0.49 & 0.06 & & 0.11 & & 1.61 & 2.94 & 5.9 \\
\hline & & $\mathrm{A}(\mathrm{N}=5)$ & 0.90 & 0.44 & 2.29 & 37.5 & 0.24 & 1.40 & 2.60 & 0.15 & 0.08 & 0.88 & & 1.84 & 1.08 & 51.0 \\
\hline & & \pm & 0.34 & 0.07 & 0.36 & 1.7 & 0.09 & 0.49 & 0.55 & 0.03 & 0.05 & 0.13 & & 0.35 & 0.92 & 3.3 \\
\hline & \multirow{4}{*}{ SCV } & $\mathrm{CS}(\mathrm{N}=3)$ & 1.26 & 0.74 & 2.67 & 39.9 & 0.27 & 1.98 & 2.84 & 0.16 & 0.11 & 0.95 & & 2.66 & 1.84 & 45.3 \\
\hline & & \pm & 0.32 & 0.21 & 0.90 & 4.5 & 0.11 & 0.58 & 0.26 & 0.05 & 0.11 & 0.37 & & 0.52 & 0.11 & 6.5 \\
\hline & & $\mathrm{A}(\mathrm{N}=5)$ & 1.38 & 1.01 & 3.40 & 41.2 & 0.27 & 2.33 & 3.88 & 0.19 & 0.07 & 0.96 & & 2.09 & 1.40 & 42.2 \\
\hline & & \pm & 0.35 & 0.45 & 0.99 & 3.2 & 0.09 & 0.85 & 0.81 & 0.03 & 0.05 & 0.21 & & 0.74 & 0.34 & 4.2 \\
\hline & & $\mathrm{CS}(\mathrm{N}=8)$ & 1.69 & 0.46 & 2.17 & 39.0 & 0.36 & 1.67 & 1.94 & 0.14 & 0.02 & 0.57 & & 2.19 & 3.44 & 46.4 \\
\hline & & \pm & 0.52 & 0.09 & 0.49 & 3.9 & 0.25 & 0.70 & 0.63 & 0.05 & 0.03 & 0.14 & & 0.70 & 2.80 & 2.9 \\
\hline & IVDJ-S & R (IVDJ-S XV) & 1.13 & 0.53 & 3.32 & 37.8 & 0.22 & 1.23 & 2.83 & 0.15 & & 1.06 & & 1.51 & 3.20 & 47.0 \\
\hline & & $A(N=3)$ & 2.23 & 0.69 & 3.06 & 42.3 & 0.40 & 2.56 & 2.95 & 0.16 & & 0.97 & & 1.38 & 4.58 & 40.4 \\
\hline & & \pm & 1.17 & 0.20 & 0.61 & 3.7 & 0.08 & 1.02 & 0.69 & 0.05 & & 0.40 & & 0.33 & 5.67 & 10.0 \\
\hline & IVDI-T & A (IVDJ-T 96) & 1.01 & 0.91 & 3.76 & 35.6 & & 1.62 & 2.90 & 0.24 & & 0.68 & & 2.66 & 3.77 & 44.9 \\
\hline & & A (IVDJ-T 133) & 0.59 & 0.66 & 3.75 & 42.9 & 0.17 & 1.07 & 1.38 & 0.10 & 0.02 & 0.55 & & 1.22 & 0.62 & 46.9 \\
\hline & PNS & $\mathrm{CS}(\mathrm{N}=3)$ & 1.01 & 0.56 & 2.20 & 38.3 & & 2.52 & 1.91 & 0.16 & 0.13 & 3.90 & & & 0.75 & 48.6 \\
\hline
\end{tabular}




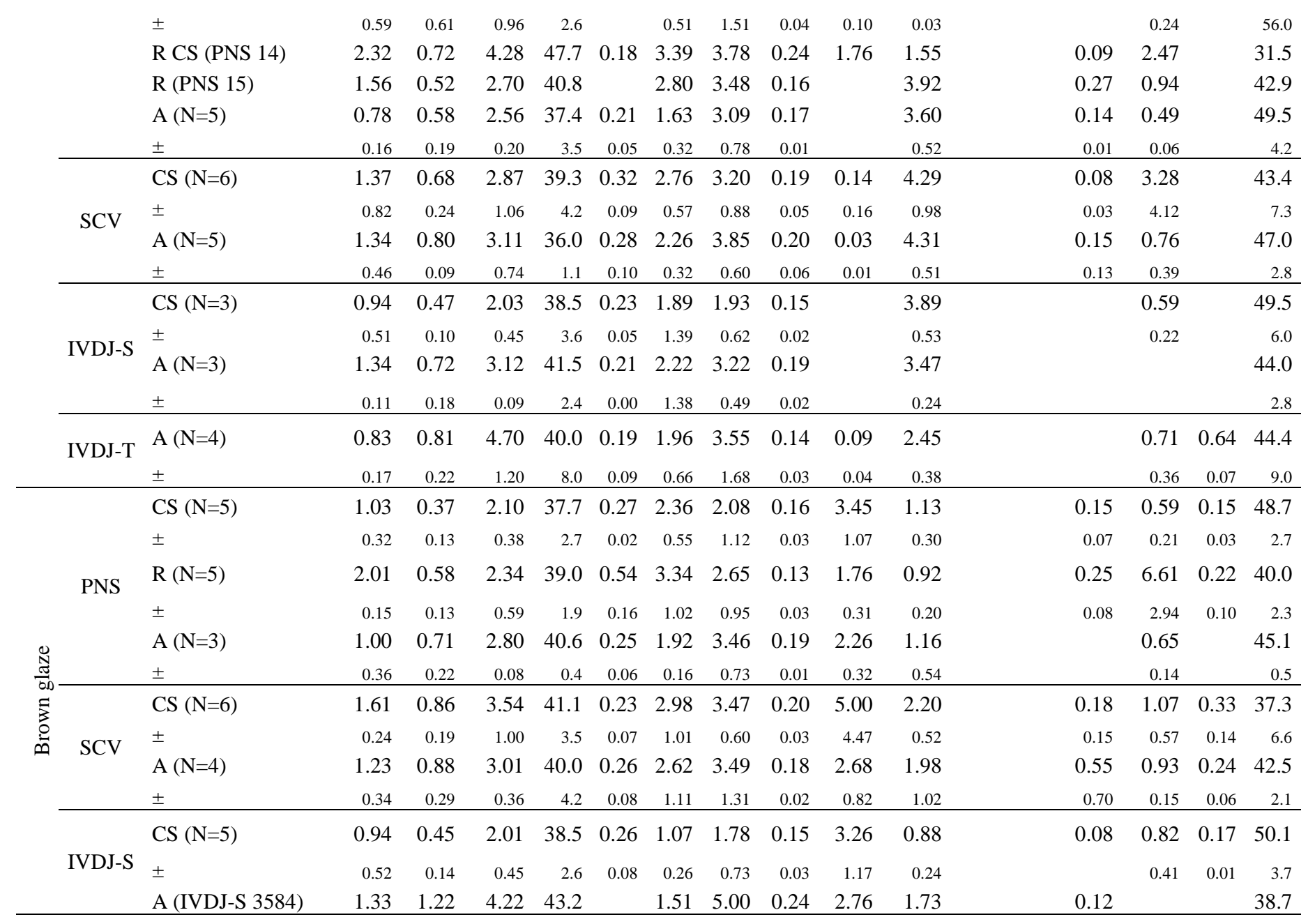




\begin{tabular}{|c|c|c|c|c|c|c|c|c|c|c|c|c|c|c|c|c|c|c|c|c|c|}
\hline Colour & Sample & Technique & $\mathrm{Na}_{2} \mathrm{O}$ & $\mathrm{MgO}$ & $\mathrm{Al}_{2} \mathrm{O}_{3}$ & $\mathrm{SiO}_{2}$ & $\mathrm{Cl}$ & $\mathrm{K}_{2} \mathrm{O}$ & $\mathrm{CaO}$ & $\mathrm{TiO}_{2}$ & $\mathrm{MnO}$ & $\mathrm{Fe}_{2} \mathrm{O}_{3}$ & $\mathrm{CoO}$ & $\mathrm{NiO}$ & $\mathrm{CuO}$ & $\mathrm{ZnO}$ & $\mathrm{As}_{2} \mathrm{O}_{5}$ & $\mathrm{SnO}_{2}$ & $\mathrm{BaO}$ & $\mathrm{PbO}$ & $\mathrm{Bi}_{2} \mathrm{O}_{3}$ \\
\hline \multirow{38}{*}{ White } & PNS 04 & $\mathrm{~F}$ & 1.49 & 0.29 & 0.42 & 29.2 & 0.98 & 0.21 & 0.28 & & & 0.21 & & & & & & 11.65 & & 55.3 & \\
\hline & PNS 05 & CS & 2.19 & 0.53 & 2.01 & 42.3 & 0.69 & 2.75 & 2.64 & 0.16 & & 0.55 & & & & & & 7.66 & & 38.6 & \\
\hline & PNS 06 & CS & 2.54 & 0.73 & 1.77 & 42.4 & 0.49 & 2.84 & 2.19 & 0.11 & & 0.43 & & & & & & 7.02 & & 39.4 & \\
\hline & PNS 07 & $\mathrm{R}$ & 2.97 & 0.44 & 1.95 & 39.9 & 0.63 & 3.63 & 1.95 & 0.20 & & 0.46 & & & & & & 7.58 & & 40.3 & \\
\hline & PNS 08 & $\mathrm{R}$ & 1.78 & 0.48 & 1.73 & 38.4 & 0.69 & 3.22 & 2.30 & 0.11 & & 0.51 & & & 0.17 & & & 7.64 & & 43.0 & \\
\hline & PNS 09 & $\mathrm{R}$ & 2.60 & 0.29 & 1.35 & 35.6 & 0.99 & 2.08 & 1.17 & & 0.15 & 0.25 & & & 0.20 & & & 7.90 & & 47.4 & \\
\hline & PNS 10 & $\mathrm{R}$ & 1.79 & 0.32 & 1.47 & 37.3 & 1.30 & 2.62 & 1.21 & 0.08 & & 0.28 & & & 0.20 & & & 7.32 & & 46.1 & \\
\hline & PNS 11 & CS & 1.89 & 0.31 & 0.89 & 35.4 & 0.88 & 2.91 & 1.19 & 0.06 & & 0.25 & & & 0.13 & & & 8.27 & & 47.9 & \\
\hline & PNS 12 & CS & 2.48 & 0.45 & 2.64 & 42.7 & 0.75 & 3.23 & 1.84 & 0.10 & & 0.51 & & & & & & 5.07 & & 40.3 & \\
\hline & PNS 13 & $\mathrm{R}$ & 1.74 & 0.24 & 1.13 & 34.9 & 1.26 & 2.80 & 1.47 & 0.07 & & 0.42 & & & & & & 8.58 & & 47.4 & \\
\hline & PNS 14 & R CS & 2.98 & 0.91 & 2.61 & 49.2 & 0.19 & 2.99 & 4.07 & 0.21 & & 0.89 & & & 0.08 & & & 6.54 & & 29.4 & \\
\hline & PNS 15 & $\mathrm{R}$ & 2.03 & 0.47 & 1.97 & 41.0 & & 2.50 & 2.99 & 0.18 & & 0.67 & & & 0.38 & & & 6.97 & & 40.9 & \\
\hline & PNS 17 & $\mathrm{R}$ & 3.47 & 0.39 & 1.36 & 40.7 & 0.87 & 1.89 & 1.67 & & & 0.33 & & & 0.16 & & & 7.93 & & 41.3 & \\
\hline & PNS 18 & $\mathrm{R}$ & 2.62 & 0.72 & 2.38 & 39.9 & 0.96 & 3.15 & 2.78 & 0.12 & & 0.49 & & & 0.11 & & & 7.89 & & 38.9 & \\
\hline & PNS 19 & CS & 3.19 & 0.50 & 2.29 & 41.0 & 0.79 & 1.97 & 2.41 & 0.14 & & 0.54 & & & & & & 6.25 & & 40.9 & \\
\hline & PNS 20 & CS & 1.93 & 0.36 & 1.65 & 37.6 & 0.82 & 1.43 & 1.77 & 0.12 & & 0.40 & & & 0.22 & & & 6.03 & & 47.8 & \\
\hline & PNS 21 & $A$ & 2.13 & 0.61 & 2.28 & 41.1 & 0.51 & 1.49 & 2.89 & 0.15 & & 0.61 & & & & & & 7.80 & & 40.5 & \\
\hline & PNS 22 & $A$ & 2.47 & 0.45 & 3.19 & 41.6 & 0.34 & 1.39 & 2.62 & 0.17 & 0.05 & 0.85 & & & & & & 4.73 & & 42.2 & \\
\hline & PNS 23 & CS & 2.73 & 0.44 & 1.70 & 42.1 & 0.82 & 3.77 & 1.87 & 0.12 & & 0.39 & & & & & & 6.64 & & 39.4 & \\
\hline & PNS 24 & $A$ & 2.65 & 0.90 & 1.52 & 47.1 & 1.03 & 1.86 & 1.68 & 0.10 & & 0.43 & & & & & & 7.15 & & 35.6 & \\
\hline & PNS 25 & $A$ & 2.63 & 0.57 & 2.68 & 46.3 & 0.75 & 3.14 & 3.10 & 0.16 & & 0.71 & & & & & & 6.71 & & 33.2 & \\
\hline & PNS 26 & $A$ & 2.59 & 0.64 & 3.23 & 43.4 & 0.60 & 3.57 & 3.60 & 0.16 & & 0.68 & & & & & & 5.60 & & 36.0 & \\
\hline & PNS 27 & CS & 2.48 & 0.65 & 1.56 & 40.0 & 0.99 & 1.82 & 1.32 & 0.13 & & 0.36 & & & 0.09 & & & 8.64 & & 42.0 & \\
\hline & PNS 28 & CS & 1.73 & 0.64 & 2.34 & 43.5 & 0.57 & 3.74 & 2.53 & 0.16 & & 0.78 & & & 0.16 & & & 6.52 & & 37.4 & \\
\hline & PNS 29 & $A$ & 2.84 & 0.46 & 2.54 & 44.4 & 1.00 & 1.99 & 1.92 & 0.14 & & 0.48 & & & & & & 5.60 & & 38.7 & \\
\hline & PNS 30 & $\mathrm{R}$ & 2.11 & 0.34 & 0.93 & 44.8 & 0.48 & 2.68 & 1.23 & & 0.07 & 0.32 & & & 0.13 & & & 6.40 & & 40.5 & \\
\hline & SCV $8 i 7532$ & $A$ & 2.71 & 0.45 & 2.69 & 41.9 & 0.62 & 2.24 & 2.43 & 0.14 & & 0.52 & & & & & & 5.79 & & 40.5 & \\
\hline & SCV $10 \mathrm{EF} 175^{*}$ & $A$ & 2.40 & 0.83 & 3.10 & 42.0 & 0.32 & 2.48 & 4.06 & 0.20 & 0.05 & 0.93 & & & 0.64 & & & 7.02 & & 36.0 & \\
\hline & SCV 10DF7637 * & $A$ & 1.82 & 1.20 & 2.54 & 41.6 & 0.23 & 1.86 & 3.18 & 0.19 & & 0.92 & & & 0.25 & & & 13.68 & & 32.5 & \\
\hline & SCV 20i2989 * & $A$ & 1.90 & 0.91 & 2.34 & 38.4 & 0.30 & 1.95 & 2.05 & 0.09 & & 0.72 & & & 0.13 & & & 10.95 & & 40.3 & \\
\hline & SCV $27 i 3426$ * & CS & 1.99 & 0.87 & 1.84 & 42.5 & 0.29 & 1.97 & 2.51 & 0.13 & & 0.70 & & & 0.12 & & & 6.49 & & 40.6 & \\
\hline & SCV 30F7756 & CS & 2.23 & 0.77 & 2.19 & 47.9 & 0.25 & 4.29 & 2.24 & 0.14 & 0.05 & 0.48 & & & 0.15 & & & 10.02 & & 29.3 & \\
\hline & SCV 33Bi3839 * & CS & 2.22 & 0.67 & 1.81 & 44.3 & 0.31 & 3.10 & 1.49 & 0.11 & 0.03 & 0.53 & & & 0.06 & & & 8.40 & & 37.0 & \\
\hline & SCV 33Bi3872 & CS & 2.03 & 0.44 & 1.78 & 40.0 & 0.59 & 2.65 & 1.75 & 0.12 & 0.03 & 0.61 & & & 0.06 & & & 7.60 & & 42.4 & \\
\hline & SCV 3333BF4013 * & CS & 1.14 & 1.16 & 4.77 & 47.1 & 0.22 & 2.09 & 3.54 & 0.18 & 0.03 & 1.02 & & & 0.20 & & & 12.51 & & 26.1 & \\
\hline & SCV 37AF4167 * & $A$ & 2.73 & 0.94 & 2.64 & 50.2 & 0.19 & 1.93 & 2.87 & 0.11 & & 0.59 & & & & & & 9.00 & & 28.8 & \\
\hline & SCV 37AF4179 * & $A$ & 1.78 & 1.82 & 2.76 & 43.0 & & 3.70 & 2.60 & 0.13 & & 0.76 & & & 0.11 & & & 11.21 & & 32.2 & \\
\hline & SCV $45 \mathrm{M} 4260$ * & CS & 3.06 & 0.51 & 2.30 & 42.9 & 0.55 & 2.41 & 2.56 & 0.17 & & 0.67 & & & & & & 7.88 & & 37.1 & \\
\hline
\end{tabular}




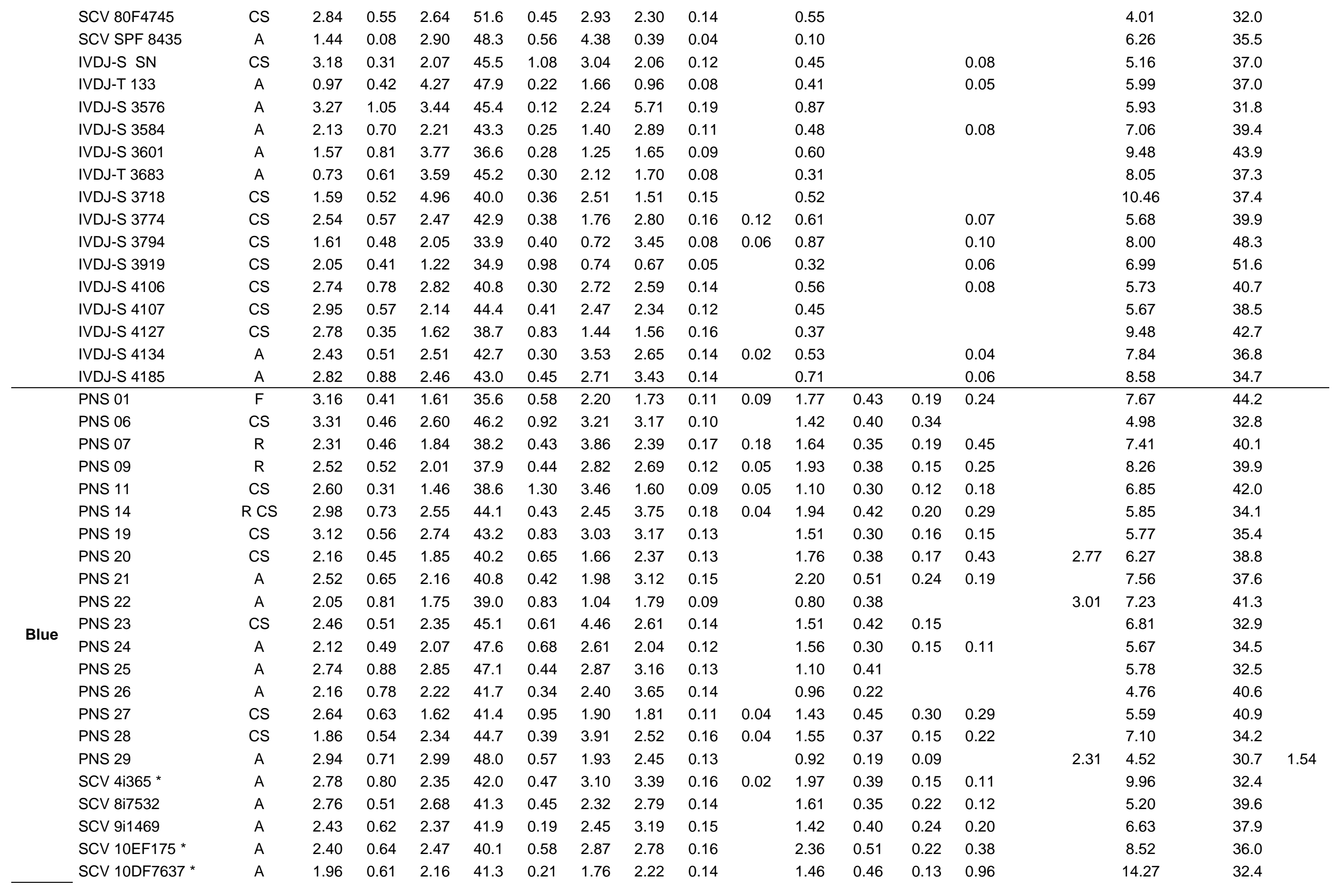




\begin{tabular}{|c|c|c|c|c|c|c|c|c|c|c|c|c|c|c|c|c|c|c|}
\hline SCV 14CF2686 * & $\mathrm{R}$ & 2.01 & 0.78 & 2.19 & 39.4 & 0.23 & 1.97 & 2.65 & 0.15 & & 1.51 & 0.30 & 0.21 & 0.45 & & 12.56 & & 35.6 \\
\hline SCV 20i2989 * & $A$ & 2.64 & 0.76 & 2.10 & 40.5 & 0.34 & 2.55 & 2.53 & 0.12 & & 1.92 & 0.53 & 0.23 & 0.29 & & 8.51 & & 37.0 \\
\hline SCV 21AM3076 * & $A$ & 1.77 & 0.65 & 1.66 & 39.6 & 0.20 & 3.09 & 2.19 & 0.12 & 0.09 & 1.32 & 0.27 & 0.14 & 0.42 & & 8.80 & & 39.7 \\
\hline sCV 27i3426 * & CS & 2.29 & 0.62 & 1.57 & 41.6 & 0.32 & 2.27 & 2.17 & 0.11 & 0.02 & 1.72 & 0.50 & 0.21 & 0.42 & & 6.82 & & 39.3 \\
\hline SCV 30F7756 & CS & 2.94 & 0.50 & 2.13 & 47.5 & 0.16 & 2.50 & 2.07 & 0.13 & 0.04 & 1.34 & 0.20 & & 0.34 & & 9.94 & & 30.2 \\
\hline SCV 33Bi3839 * & CS & 2.47 & 0.72 & 1.88 & 42.6 & 0.31 & 3.46 & 2.59 & 0.20 & & 0.87 & 0.29 & 0.12 & 0.29 & & 9.28 & & 34.9 \\
\hline SCV 3333BF4013 * & CS & 1.73 & 0.60 & 2.87 & 40.0 & 0.15 & 2.22 & 2.20 & 0.15 & & 1.68 & 0.39 & 0.21 & 0.41 & & 18.74 & & 28.6 \\
\hline SCV 37AF4167 * & $A$ & 2.37 & 0.82 & 2.49 & 43.4 & 0.22 & 1.82 & 3.02 & 0.17 & & 1.93 & 0.50 & 0.17 & 0.33 & & 12.09 & & 30.6 \\
\hline SCV 37AF4179 * & $A$ & 2.01 & 0.64 & 1.85 & 44.6 & 0.31 & 4.15 & 2.22 & 0.14 & & 1.85 & 0.55 & 0.17 & 0.27 & & 9.59 & & 31.7 \\
\hline SCV 45M4260 * & CS & 3.39 & 0.39 & 1.83 & 41.9 & 1.00 & 2.12 & 1.67 & 0.12 & & 1.71 & 0.44 & 0.23 & 0.27 & & 8.15 & & 36.8 \\
\hline SCV 80F4745 & CS & 3.01 & 0.68 & 2.15 & 45.7 & 0.32 & 2.13 & 2.12 & 0.40 & 0.06 & 0.75 & 0.16 & 0.11 & 0.12 & & 3.77 & & 38.5 \\
\hline SCV 86i4886 * & $\mathrm{F}$ & 2.53 & 0.72 & 2.22 & 43.2 & 0.35 & 3.73 & 3.15 & 0.12 & 0.02 & 2.09 & 0.42 & 0.11 & 0.05 & & 11.27 & 0.32 & 29.7 \\
\hline IVDJ-S SN & CS & 3.22 & 0.42 & 2.01 & 45.2 & 0.77 & 3.12 & 2.52 & 0.11 & 0.04 & 1.20 & 0.23 & 0.22 & 0.14 & & 7.02 & & 33.7 \\
\hline IVDJ-T 133 & $A$ & 0.90 & 0.82 & 3.20 & 41.2 & 0.31 & 1.12 & 1.09 & 0.10 & 0.00 & 0.61 & 0.29 & 0.17 & 0.07 & & 3.94 & & 46.2 \\
\hline IVDJ-S 3561 & $A$ & 2.89 & 1.05 & 2.84 & 43.2 & 0.61 & 3.79 & 4.22 & 0.16 & 0.06 & 1.10 & 0.34 & 0.12 & & & 6.78 & & 32.8 \\
\hline IVDJ-S 3576 & $A$ & 3.56 & 0.85 & 2.82 & 44.5 & 0.24 & 2.20 & 3.21 & 0.20 & 0.06 & 2.85 & 0.61 & 0.26 & 0.27 & & 6.00 & & 32.4 \\
\hline IVDJ-S 3584 & $A$ & 3.22 & 0.64 & 2.50 & 42.1 & 0.49 & 1.61 & 2.49 & 0.10 & & 1.96 & 0.48 & 0.27 & 0.19 & & 6.43 & & 37.5 \\
\hline IVDJ-S 3591 & $A$ & 3.30 & 0.44 & 2.31 & 38.9 & 0.97 & 1.71 & 2.17 & 0.13 & & 2.09 & 0.32 & 0.22 & 0.30 & & 6.32 & & 40.8 \\
\hline IVDJ-S 3601 & $A$ & 1.71 & 0.92 & 3.67 & 37.9 & 0.25 & 1.31 & 1.31 & 0.12 & 0.02 & 0.90 & 0.50 & 0.09 & 0.07 & & 8.34 & & 42.8 \\
\hline IVDJ-T 3683 & $A$ & 0.66 & 0.96 & 4.14 & 46.3 & & 2.50 & 2.95 & 0.10 & 0.12 & 0.80 & 0.26 & 0.12 & 0.33 & & 6.42 & & 34.3 \\
\hline IVDJ-T 4095 & $A$ & 4.71 & 0.39 & 4.23 & 40.7 & 1.04 & 2.73 & 1.06 & 0.11 & & 1.68 & 0.32 & & 0.25 & & 4.48 & & 38.3 \\
\hline IVDJ-S 4098 & $A$ & 2.14 & 0.47 & 2.00 & 41.6 & 0.82 & 3.42 & 1.65 & 0.16 & & 1.92 & 0.34 & 0.12 & 0.15 & 0.04 & 7.44 & & 37.8 \\
\hline IVDJ-S 4106 & CS & 3.06 & 0.42 & 2.62 & 40.8 & 0.83 & 2.27 & 1.70 & 0.10 & & 2.12 & 0.53 & 0.18 & 0.32 & & 4.96 & & 40.1 \\
\hline IVDJ-S 4107 & CS & 3.38 & 0.63 & 2.38 & 43.0 & 0.43 & 2.58 & 2.69 & 0.14 & 0.05 & 1.77 & 0.50 & 0.11 & 0.18 & & 5.82 & & 36.3 \\
\hline IVDJ-S 4127 & CS & 2.72 & 0.22 & 1.51 & 38.6 & 0.61 & 1.42 & 1.12 & 0.09 & 0.03 & 1.33 & 0.54 & 0.29 & 0.35 & & 6.25 & & 44.9 \\
\hline IVDJ-S 4134 & $A$ & 2.24 & 0.51 & 3.14 & 40.6 & 0.19 & 3.59 & 2.68 & 0.16 & 0.06 & 3.58 & 1.22 & 0.48 & 0.94 & & 9.69 & & 30.9 \\
\hline IVDJ-S 4185 & A & 3.60 & 1.52 & 4.72 & 45.9 & 0.10 & 2.81 & 6.52 & 0.22 & 0.05 & 4.06 & 1.27 & 0.58 & & & 5.48 & & 23.2 \\
\hline PNS 02 & $\mathrm{~F}$ & 1.17 & 0.69 & 3.03 & 38.6 & 0.21 & 2.01 & 3.38 & 0.18 & & 0.80 & & & 1.94 & & 1.26 & & 46.8 \\
\hline PNS 03 & $\mathrm{~F}$ & 1.00 & 0.12 & 0.57 & 32.9 & 0.36 & 0.30 & 0.37 & & & 0.27 & & & 2.98 & & 7.17 & & 54.0 \\
\hline PNS 05 & CS & 1.81 & 0.65 & 3.56 & 41.4 & 0.27 & 2.44 & 3.74 & 0.38 & & 0.95 & & & 1.32 & & 2.03 & & 41.3 \\
\hline PNS 06 & CS & 1.65 & 0.65 & 2.22 & 37.8 & 0.43 & 2.05 & 2.46 & 0.13 & & 0.63 & & & 0.88 & & 4.13 & & 47.0 \\
\hline PNS 07 & $\mathrm{R}$ & 1.15 & 0.61 & 2.52 & 40.0 & 0.24 & 3.08 & 3.42 & 0.23 & & 0.84 & & & 2.85 & & 0.78 & & 44.3 \\
\hline PNS 09 & $\mathrm{R}$ & 2.31 & 0.48 & 1.98 & 37.3 & 0.47 & 2.54 & 2.49 & 0.10 & & 0.84 & & & 2.37 & & 6.16 & & 42.9 \\
\hline PNS 10 & $\mathrm{R}$ & 0.80 & 0.39 & 2.10 & 33.8 & & 1.31 & 2.68 & 0.11 & & 0.88 & & & 2.08 & & 0.70 & & 55.1 \\
\hline PNS 11 & CS & 1.39 & 0.29 & 1.72 & 39.2 & 0.30 & 2.88 & 1.82 & 0.13 & & 0.63 & & & 1.66 & & 2.26 & & 47.7 \\
\hline PNS 12 & CS & 1.30 & 0.29 & 2.38 & 38.0 & 0.33 & 1.18 & 1.80 & 0.17 & 0.05 & 0.77 & & & 2.05 & 0.20 & 1.68 & & 49.8 \\
\hline PNS 15 & $\mathrm{R}$ & 0.86 & 0.42 & 1.99 & 36.4 & & 1.89 & 2.59 & 0.15 & & 0.67 & & & 2.22 & & 0.99 & & 51.8 \\
\hline PNS 16 & $\mathrm{R}$ & 1.22 & 0.53 & 1.98 & 34.4 & 0.66 & 1.34 & 2.00 & 0.12 & & 0.61 & & & 2.17 & & 1.76 & & 53.2 \\
\hline PNS 17 & $\mathrm{R}$ & 3.06 & 0.34 & 1.04 & 36.0 & 0.55 & 1.29 & 2.22 & 0.03 & & 0.77 & & & 6.23 & & 7.18 & & 41.3 \\
\hline
\end{tabular}




\begin{tabular}{|c|c|c|c|c|c|c|c|c|c|c|c|c|c|c|c|c|}
\hline PNS 19 & CS & 1.48 & 0.62 & 3.82 & 43.2 & & 2.76 & 3.11 & 0.26 & 0.30 & 1.39 & & 1.98 & & 1.82 & 39.2 \\
\hline PNS 21 & $A$ & 1.03 & 0.48 & 2.59 & 37.8 & 0.16 & 1.21 & 2.89 & 0.19 & & 0.88 & & 1.51 & & & 51.5 \\
\hline PNS 22 & $A$ & 0.49 & 0.38 & 2.34 & 34.5 & 0.20 & 0.81 & 2.22 & 0.15 & & 0.75 & & 1.59 & & 0.45 & 56.4 \\
\hline PNS 24 & $A$ & 1.29 & 0.34 & 1.79 & 38.1 & 0.39 & 1.43 & 1.98 & 0.13 & 0.05 & 1.05 & & 2.34 & & 2.41 & 48.7 \\
\hline PNS 26 & $A$ & 1.09 & 0.50 & 2.66 & 38.3 & 0.23 & 2.15 & 3.36 & 0.17 & 0.12 & 0.96 & & 1.67 & & 1.02 & 48.0 \\
\hline PNS 28 & CS & 1.53 & 0.39 & 2.95 & 44.4 & 0.31 & 3.21 & 1.72 & 0.22 & & 1.00 & & 2.17 & & 1.45 & 40.7 \\
\hline PNS 29 & $A$ & 0.60 & 0.50 & 2.09 & 39.0 & 0.22 & 1.41 & 2.57 & 0.12 & & 0.74 & & 2.07 & & 0.45 & 50.3 \\
\hline SCV 9i1469 & $A$ & 1.83 & 0.80 & 4.10 & 39.6 & 0.16 & 2.13 & 3.78 & 0.16 & 0.13 & 1.13 & & 1.35 & & & 44.8 \\
\hline SCV 10EF175 * & $A$ & 1.62 & 0.87 & 3.09 & 39.7 & 0.36 & 2.12 & 4.15 & 0.20 & & 1.01 & & 2.06 & & 1.46 & 43.3 \\
\hline SCV $21 \mathrm{AM} 3076$ * & $A$ & 1.03 & 0.91 & 2.62 & 37.6 & 0.33 & 1.85 & 3.62 & 0.19 & 0.03 & 0.79 & & 3.29 & & 1.27 & 46.5 \\
\hline SCV 27i3426 * & CS & 1.04 & 0.74 & 1.66 & 34.7 & 0.39 & 1.55 & 2.61 & 0.11 & 0.19 & 0.78 & & 2.71 & & 1.92 & 51.6 \\
\hline SCV 30F7756 & CS & 1.63 & 0.95 & 3.40 & 42.8 & 0.27 & 2.64 & 3.13 & 0.21 & & 1.37 & & 3.16 & & 1.76 & 38.7 \\
\hline SCV 37AF4167 * & $A$ & 1.07 & 1.80 & 4.75 & 44.3 & 0.20 & 1.73 & 5.03 & 0.24 & 0.05 & 1.18 & & 2.13 & & 1.83 & 35.7 \\
\hline SCV 37AF4179 * & $A$ & 1.33 & 0.66 & 2.44 & 44.7 & 0.31 & 3.82 & 2.80 & 0.16 & & 0.69 & & 1.64 & & 1.03 & 40.4 \\
\hline SCV 80F4745 & CS & 1.12 & 0.53 & 2.94 & 42.2 & 0.16 & 1.75 & 2.77 & 0.15 & 0.04 & 0.69 & & 2.12 & & & 45.6 \\
\hline IVDJ-S SN & CS & 1.73 & 0.35 & 2.61 & 42.7 & 0.31 & 2.53 & 1.40 & 0.19 & 0.00 & 0.56 & & 1.48 & & 1.69 & 44.4 \\
\hline IVDJ-T 133 & $A$ & 0.59 & 0.66 & 3.75 & 42.9 & 0.17 & 1.07 & 1.38 & 0.10 & 0.02 & 0.55 & & 1.22 & & 0.62 & 46.9 \\
\hline IVDJ-S 3561 & $A$ & 3.58 & 0.71 & 3.18 & 46.4 & 0.46 & 3.25 & 2.83 & 0.13 & & 0.83 & & 1.09 & & 8.59 & 28.9 \\
\hline IVDJ-S 3584 & $A$ & 1.49 & 0.88 & 3.60 & 40.9 & & 1.39 & 3.69 & 0.22 & & 1.42 & & 1.73 & & & 44.7 \\
\hline IVDJ-S 3718 & CS & 1.21 & 0.56 & 2.56 & 39.0 & 0.21 & 1.93 & 1.92 & 0.21 & & 0.53 & & 2.59 & & 2.45 & 46.9 \\
\hline IVDJ-S 3774 & CS & 1.16 & 0.50 & 2.71 & 42.9 & 0.20 & 1.98 & 2.56 & 0.14 & 0.00 & 0.79 & & 1.69 & 0.11 & 1.30 & 43.9 \\
\hline IVDJ-S 3794 & CS & 2.72 & 0.36 & 2.05 & 36.0 & 0.87 & 0.76 & 2.46 & 0.11 & 0.02 & 0.71 & & 1.96 & & 7.84 & 44.1 \\
\hline IVDJ-S 3919 & CS & 2.08 & 0.43 & 1.21 & 31.9 & 0.60 & 0.57 & 0.69 & 0.04 & & 0.33 & & 2.45 & & 7.92 & 51.8 \\
\hline IVDJ-S 4098 & $A$ & 1.63 & 0.48 & 2.40 & 39.5 & 0.35 & 3.05 & 2.32 & 0.12 & 0.05 & 0.67 & 0.05 & 1.32 & & 0.58 & 47.5 \\
\hline IVDJ-S 4106 & CS & 1.31 & 0.40 & 2.23 & 37.9 & 0.24 & 1.42 & 1.86 & 0.16 & 0.05 & 0.54 & & 2.82 & & 1.53 & 49.5 \\
\hline IVDJ-S 4107 & CS & 1.57 & 0.59 & 2.12 & 42.9 & 0.20 & 2.29 & 2.41 & 0.17 & & 0.52 & & 1.26 & & 1.63 & 44.3 \\
\hline IVDJ-S 4127 & CS & 1.76 & 0.46 & 1.84 & 38.2 & 0.24 & 1.89 & 2.21 & 0.14 & & 0.62 & & 3.25 & & 3.18 & 46.2 \\
\hline IVDJ-S XV & $\mathrm{R}$ & 1.13 & 0.53 & 3.32 & 37.8 & 0.22 & 1.23 & 2.83 & 0.15 & & 1.06 & & 1.51 & & 3.20 & 47.0 \\
\hline IVDJ-T 96 & A & 1.01 & 0.91 & 3.76 & 35.6 & & 1.62 & 2.90 & 0.24 & & 0.68 & & 2.66 & & 3.77 & 1.98 \\
\hline PNS 05 & CS & 1.68 & 1.25 & 3.24 & 39.1 & & 2.32 & 3.61 & 0.18 & 0.20 & 3.92 & & & & 1.01 & 43.5 \\
\hline PNS 11 & CS & 0.63 & 0.12 & 1.36 & 35.4 & & 2.14 & 0.71 & & & 3.92 & & & & 0.55 & 55.1 \\
\hline PNS 14 & R CS & 2.32 & 0.72 & 4.28 & 47.7 & 0.18 & 3.39 & 3.78 & 0.24 & 1.76 & 1.55 & & 0.09 & & 2.47 & 31.5 \\
\hline PNS 15 & $\mathrm{R}$ & 1.56 & 0.52 & 2.70 & 40.8 & & 2.80 & 3.48 & 0.16 & & 3.92 & & 0.27 & & 0.94 & 42.9 \\
\hline PNS 21 & A & 0.79 & 0.55 & 2.64 & 37.3 & 0.14 & 1.39 & 3.44 & 0.17 & & 3.73 & & & & 0.52 & 49.4 \\
\hline PNS 22 & $A$ & 0.50 & 0.54 & 2.48 & 34.2 & 0.18 & 1.26 & 2.68 & 0.17 & 0.50 & 3.77 & & 0.13 & & 0.49 & 53.2 \\
\hline PNS 24 & $A$ & 0.84 & 0.34 & 2.30 & 33.5 & 0.26 & 1.61 & 2.08 & 0.16 & & 4.30 & & 0.14 & & 0.46 & 54.0 \\
\hline PNS 25 & $A$ & 0.89 & 0.88 & 2.85 & 41.0 & 0.24 & 2.01 & 4.16 & & & 2.91 & & & & 0.57 & 44.5 \\
\hline PNS 27 & CS & 0.71 & 0.31 & 1.99 & 40.3 & 0.25 & 3.11 & 1.41 & 0.13 & 0.07 & 3.87 & & & & 0.69 & 47.1 \\
\hline PNS 29 & $A$ & 0.86 & 0.58 & 2.54 & 40.8 & 0.20 & 1.88 & 3.07 & 0.16 & & 3.31 & & & & 0.41 & 46.2 \\
\hline
\end{tabular}




\begin{tabular}{|c|c|c|c|c|c|c|c|c|c|c|c|c|c|c|c|c|c|}
\hline SCV $4 i 365$ * & $A$ & 2.07 & 0.95 & 3.49 & 36.9 & 0.35 & 2.71 & 4.74 & 0.19 & & 4.75 & & 0.11 & & 1.22 & & 42.5 \\
\hline SCV $9 i 1469$ & $A$ & 1.29 & 0.79 & 3.67 & 37.2 & 0.14 & 1.92 & 3.82 & 0.19 & 0.03 & 3.51 & & 0.17 & & 0.48 & & 46.7 \\
\hline SCV 10DF7637 * & $A$ & 1.27 & 0.76 & 3.76 & 35.2 & 0.32 & 1.98 & 3.96 & 0.28 & & 4.51 & 0.07 & 0.35 & & 0.42 & & 47.2 \\
\hline SCV 20i2989 * & $A$ & 1.28 & 0.72 & 2.25 & 34.9 & & 2.42 & 3.10 & 0.11 & & 4.67 & & 0.00 & & 1.14 & & 49.4 \\
\hline SCV 21AM3076 * & $A$ & 0.78 & 0.76 & 2.38 & 35.6 & 0.32 & 2.26 & 3.61 & 0.21 & 0.02 & 4.09 & & 0.12 & & 0.53 & & 49.4 \\
\hline SCV 27i3426 * & CS & 1.10 & 0.54 & 2.06 & 34.3 & 0.31 & 2.01 & 3.00 & 0.19 & & 4.89 & & 0.07 & & 0.65 & & 50.8 \\
\hline SCV 33Bi3839 * & CS & 0.00 & 1.05 & 3.01 & 35.8 & 0.40 & 3.09 & 4.31 & 0.19 & & 5.22 & & 0.06 & & & & 46.9 \\
\hline SCV 33Bi3872 & CS & 1.74 & 0.46 & 2.30 & 36.9 & & 2.85 & 2.01 & 0.16 & 0.32 & 4.16 & & & & & & 49.1 \\
\hline SCV 3333BF4013 * & CS & 1.92 & 0.90 & 4.92 & 44.8 & 0.19 & 3.28 & 4.13 & 0.29 & 0.05 & 4.75 & & & & 1.16 & & 33.6 \\
\hline SCV 45M4260 * & CS & 2.32 & 0.60 & 2.34 & 42.7 & 0.37 & 3.25 & 2.62 & 0.18 & 0.05 & 2.47 & & 0.11 & & 8.03 & & 35.0 \\
\hline SCV 80F4745 & CS & 1.14 & 0.53 & 2.58 & 41.3 & & 2.10 & 3.11 & 0.15 & & 4.24 & & & & & & 44.9 \\
\hline IVDJ-S SN & CS & 1.46 & 0.39 & 1.80 & 42.1 & 0.19 & 3.35 & 2.32 & 0.15 & & 3.43 & & 0.07 & 0.05 & 0.74 & & 44.0 \\
\hline IVDJ-T 133 & $A$ & 0.86 & 0.68 & 5.78 & 39.0 & 0.13 & 1.50 & 4.35 & 0.16 & 0.06 & 2.67 & & 0.08 & & 0.29 & 0.60 & 43.9 \\
\hline IVDJ-S 3584 & $A$ & 1.37 & 0.87 & 3.23 & 41.5 & & 1.38 & 3.71 & 0.21 & & 3.28 & & & & & & 44.4 \\
\hline IVDJ-S 3591 & A & 1.43 & 0.77 & 3.10 & 39.2 & 0.21 & 1.46 & 3.23 & & 0.14 & 3.73 & & 0.19 & & & & 46.6 \\
\hline IVDJ-T 3683 & $A$ & 0.62 & 0.96 & 4.40 & 51.5 & & 2.93 & 3.46 & 0.13 & & 2.73 & & & & 1.06 & & 32.2 \\
\hline IVDJ-S 3919 & CS & 0.44 & 0.59 & 1.75 & 35.0 & 0.29 & 0.59 & 1.21 & 0.12 & & 3.77 & & & & 0.43 & & 55.9 \\
\hline IVDJ-T 4095 & $A$ & 0.80 & 0.57 & 3.13 & 35.6 & & 1.76 & 1.24 & 0.10 & 0.13 & 2.49 & & & & 0.93 & & 53.2 \\
\hline IVDJ-S 4098 & $A$ & 1.21 & 0.52 & 3.05 & 43.9 & 0.22 & 3.81 & 2.72 & 0.17 & & 3.38 & & & & & & 41.0 \\
\hline IVDJ-S 4106 & CS & 0.93 & 0.44 & 2.54 & 38.5 & 0.20 & 1.73 & 2.26 & 0.16 & & 4.47 & & & & & & 48.7 \\
\hline IVDJ-T 96 & $A$ & 1.03 & 1.04 & 5.48 & 33.8 & 0.25 & 1.63 & 5.14 & 0.17 & 0.08 & 1.90 & & & & 0.55 & 0.69 & 48.2 \\
\hline PNS 07 & $R$ & 1.95 & 0.75 & 3.13 & 40.8 & & 4.73 & 4.11 & 0.11 & 2.26 & 1.10 & & 0.25 & & 1.78 & 0.29 & 38.7 \\
\hline PNS 08 & $\mathrm{R}$ & 1.88 & 0.48 & 1.85 & 38.1 & & 2.64 & 2.29 & 0.15 & 1.66 & 0.88 & & 0.24 & & 8.18 & & 41.6 \\
\hline PNS 09 & $\mathrm{R}$ & 2.26 & 0.54 & 2.09 & 37.9 & 0.40 & 3.11 & 2.49 & 0.11 & 1.46 & 0.78 & & 0.24 & & 7.87 & 0.15 & 40.6 \\
\hline PNS 10 & $\mathrm{R}$ & 1.93 & 0.46 & 1.86 & 36.8 & 0.72 & 2.22 & 1.52 & & 1.81 & 0.68 & & 0.37 & & 9.22 & & 42.4 \\
\hline PNS 11 & CS & 0.76 & 0.24 & 1.86 & 33.6 & & 1.97 & 1.55 & 0.11 & 5.28 & 0.74 & & 0.23 & & 0.45 & 0.12 & 53.1 \\
\hline PNS 18 & $\mathrm{R}$ & 2.04 & 0.68 & 2.80 & 41.2 & 0.49 & 4.02 & 2.82 & 0.17 & 1.61 & 1.15 & & 0.15 & & 5.98 & & 36.9 \\
\hline PNS 19 & CS & 0.79 & 0.56 & 2.77 & 36.6 & & 1.61 & 4.06 & 0.20 & 2.79 & 1.44 & & 0.11 & & 0.90 & 0.11 & 48.0 \\
\hline PNS 23 & CS & 1.42 & 0.38 & 1.95 & 40.4 & 0.29 & 2.90 & 1.68 & 0.16 & 3.26 & 1.19 & & & & 0.48 & 0.18 & 45.7 \\
\hline PNS 24 & $A$ & 0.66 & 0.52 & 2.83 & 40.6 & 0.24 & 2.10 & 2.62 & 0.20 & 2.50 & 1.78 & & & & 0.53 & & 45.4 \\
\hline PNS 25 & $A$ & 1.38 & 0.67 & 2.85 & 40.2 & 0.32 & 1.80 & 3.79 & 0.20 & 1.90 & 0.87 & & & & 0.81 & & 45.3 \\
\hline PNS 27 & CS & 0.85 & 0.26 & 1.88 & 39.3 & 0.25 & 2.65 & 1.40 & 0.16 & 2.56 & 0.93 & & 0.11 & & 0.52 & 0.14 & 49.0 \\
\hline PNS 28 & CS & 1.34 & 0.41 & 2.05 & 38.6 & 0.29 & 2.68 & 1.69 & 0.16 & 3.37 & 1.37 & & & & & 0.19 & 47.9 \\
\hline PNS 29 & $A$ & 0.95 & 0.94 & 2.70 & 40.9 & 0.19 & 1.86 & 3.96 & 0.18 & 2.37 & 0.82 & & & & 0.63 & & 44.5 \\
\hline SCV $4 i 365^{*}$ & $A$ & 1.06 & 1.20 & 3.26 & 33.8 & & 2.68 & 5.30 & 0.19 & 2.92 & 3.51 & & & & 1.07 & 0.29 & 44.8 \\
\hline SCV 10DF7637 * & $A$ & 1.49 & 0.59 & 3.12 & 42.5 & & 2.16 & 2.29 & 0.20 & 3.07 & 1.53 & & 0.15 & & & 0.26 & 42.6 \\
\hline SCV $30 F 7756$ & CS & 1.95 & 0.85 & 3.19 & 44.1 & 0.16 & 4.80 & 3.12 & 0.23 & 2.67 & 2.68 & & 0.28 & & 1.50 & & 34.5 \\
\hline SCV 33Bi3839 * & CS & 1.65 & 0.84 & 3.10 & 40.4 & 0.31 & 3.46 & 3.91 & 0.20 & 2.94 & 1.68 & & 0.09 & & 1.54 & 0.19 & 39.7 \\
\hline SCV 33Bi3872 & CS & 1.69 & 0.75 & 3.09 & 37.6 & 0.17 & 2.37 & 3.20 & 0.16 & 2.99 & 1.68 & & 0.07 & & 0.00 & 0.25 & 46.0 \\
\hline
\end{tabular}




\begin{tabular}{|c|c|c|c|c|c|c|c|c|c|c|c|c|c|c|c|}
\hline SCV 3333BF4013 * & CS & 1.43 & 1.21 & 5.36 & 46.5 & 0.19 & 2.78 & 4.47 & 0.24 & 2.60 & 2.44 & & 1.12 & 0.32 & 31.3 \\
\hline SCV 37AF4167 * & $A$ & 0.83 & 1.04 & 3.19 & 41.3 & 0.20 & 1.53 & 3.52 & 0.15 & 1.47 & 1.51 & 1.36 & 0.93 & & 43.0 \\
\hline SCV 37AF4179 * & A & 1.52 & 0.68 & 2.47 & 42.3 & 0.32 & 4.13 & 2.86 & 0.17 & 3.28 & 1.38 & 0.15 & 0.78 & 0.18 & 39.8 \\
\hline SCV 45M4260 * & CS & 1.67 & 0.63 & 2.55 & 38.2 & 0.30 & 2.45 & 2.86 & 0.17 & 4.85 & 1.87 & 0.07 & 0.97 & 0.35 & 43.0 \\
\hline SCV 80F4745 & CS & 1.27 & 0.87 & 3.95 & 39.9 & & 2.04 & 3.26 & 0.19 & 13.97 & 2.82 & 0.40 & 1.26 & 0.55 & 29.5 \\
\hline IVDJ-S SN & CS & 0.67 & 0.40 & 2.07 & 36.9 & & 1.23 & 1.51 & 0.20 & 3.39 & 0.86 & 0.08 & 0.37 & & 52.3 \\
\hline IVDJ-S 3584 & $A$ & 1.33 & 1.22 & 4.22 & 43.2 & & 1.51 & 5.00 & 0.24 & 2.76 & 1.73 & 0.12 & & & 38.7 \\
\hline IVDJ-S 3774 & CS & 0.78 & 0.65 & 2.74 & 38.6 & & 1.38 & 2.85 & 0.11 & 3.18 & 1.03 & & & 0.18 & 48.5 \\
\hline IVDJ-S 3794 & CS & 0.76 & 0.46 & 1.88 & 40.5 & 0.19 & 0.85 & 2.17 & 0.16 & 2.11 & 0.94 & & 1.30 & & 48.6 \\
\hline IVDJ-S 3919 & CS & 0.63 & 0.49 & 1.52 & 35.0 & 0.35 & 0.77 & 1.34 & 0.13 & 2.48 & 1.09 & & 1.00 & & 55.2 \\
\hline IVDJ-S 4127 & CS & 1.86 & 0.26 & 1.82 & 41.5 & 0.23 & 1.11 & 1.03 & 0.15 & 5.14 & 0.48 & & 0.60 & 0.16 & 45.7 \\
\hline
\end{tabular}

* Samples previously analysed in Coentro et al., 2014. 